\title{
Development and Validation of the Self-Efficacy in Human-Robot-Interaction Scale (SE-HRI)
}

\author{
ASTRID ROSENTHAL-VON DER PÜTTEN and NIKOLAI BOCK, \\ RWTH Aachen University, Germany
}

\begin{abstract}
This methodological article discusses the influence of individuals' beliefs about their abilities to use and control robotic technologies on their evaluation of human-robot-interaction (HRI). We conducted three surveys to develop and validate a new measure of Self-Efficacy in HRI. Exploratory factor analysis revealed a twofactorial (factors perceived self-efficacy and loss of control) solution with good reliability (Study 1, n = 201). Confirmatory factor analysis did not confirm the two-factorial structure. Instead, it revealed a better model fit for a one-factorial solution for a German (Study 2, n = 450) and an English version (Study 3, n = 209) of the scale with good indices for convergent and divergent validity. The final questionnaire with 18 items was used in two experimental studies (Study $4, \mathrm{n}=120$ ). We found that interacting with a robot increased self-efficacy and that individual changes in self-efficacy predict more positive evaluations within a student sample, but not a sample of seniors. Interviews with seniors from this study suggested shortening the scale, and revising the instructions and answering scheme. The revised scale was again subject to confirmatory factor analysis (Study 5, $\mathrm{n}=198$ ), confirming the one-factorial solution for the German and the English version of the scale. We discuss potential use cases for the scale in HRI research.
\end{abstract}

CCS Concepts: • Human-centered computing $\rightarrow$ HCI theory, concepts and models;

Additional Key Words and Phrases: Self-efficacy, human-robot-interaction, scale development, scale validation, experimental study

\section{ACM Reference format:}

Astrid Rosenthal-von der Pütten and Nikolai Bock. 2018. Development and Validation of the Self-Efficacy in Human-Robot-Interaction Scale (SE-HRI). ACM Trans. Hum.-Robot Interact. 7, 3, Article 21 (December 2018), 30 pages.

https://doi.org/10.1145/3139352

\section{INTRODUCTION}

Although robots are certainly on the move, they are still mostly found in research labs and sometimes in small controlled field trials. Only a few systems have invaded public and private spaces and are put to use for everyone, such as household devices (e.g., robotic vacuum cleaner and lawn mower). Hence, people's experiences with robots are still rather limited and their expectations are mainly based on science fiction or media coverage of the robotics topic [57]. In a recent representative survey in Germany, however, already $26 \%$ of the participants had experience with robots [34]. It was the belief of $76 \%$ of the participants that, in the future, robots will play an important role

Authors' addresses: A. M. Rosenthal-von der Pütten, N. Bock, Individual and Technology, Department of Society, Technology, and Human Factors, RWTH Aachen University, Theaterplatz 14, 52062 Aachen, Germany; email: \{arvdp, nikolai. bock\}@humtec.rwth-aachen.de.

Permission to make digital or hard copies of all or part of this work for personal or classroom use is granted without fee provided that copies are not made or distributed for profit or commercial advantage and that copies bear this notice and the full citation on the first page. Copyrights for components of this work owned by others than the author(s) must be honored. Abstracting with credit is permitted. To copy otherwise, or republish, to post on servers or to redistribute to lists, requires prior specific permission and/or a fee. Request permissions from Permissions@acm.org.

2018 Copyright is held by the owner/author(s). Publication rights licensed to ACM.

2573-9522/2018/12-ART21

https://doi.org/10.1145/3139352 
not only in industry, but also in their personal lives as service robots; and 83\% would use a service robot in their later years in order to be able to stay at home for a longer period of time instead of going into a care facility. However, expressing the intention to adopt a technology does not necessarily mean that people will actually accept and adopt a technology. In fact, one third of all assistive technologies are abandoned by their users [56]. Therefore, it is important to investigate at an early stage which factors might positively influence the acceptance and adoption of service and socially assistive robots. Along with technology-centered perceptions such as perceived ease of use and perceived usefulness, self-beliefs or, in other words, self-efficacy perceptions are a crucial factor regarding the acceptance and adoption of (new) technologies [22, 26-28, 38, 64, 65]. Humancomputer-interaction studies have repeatedly shown that increased computer self-efficacy leads to, for instance, better performance in using computers and software packages [27, 35], increased ease of use [68] and system use [27, 41], and early adoption of new technologies [16]. Since robots share a lot of characteristics with other technologies like smart-phones or computers, we assume that this correlation of self-efficacy and acceptance also holds true for HRI. Even though this relation has not been investigated yet, we are convinced that being able to include users' self-efficacy beliefs in HRI throughout the development and evaluation of new robotic technologies and areas of application will greatly benefit future HRI in the field. However, using a general self-efficacy measure would not adequately capture the scope of HRI as self-efficacy is a highly domain-specific construct [6]. The same is true for using a general technology self-efficacy measure: Albeit all similarities that robots and other technologies share, a robot differs in that it combines most of these attributes in one entity and, in addition, can be placed in a social framework due to its abilities to perceive and manipulate its physical and social environment. Robots involve other modes of interactions than computers or smartphones. Thus, it might well be that users have different beliefs of how efficient they can handle this specific kind of technology. Therefore, we developed a new measure, the Self-Efficacy in Human-Robot-Interaction Scale (SE-HRI), which captures users' perceived self-efficacy in human-robot-interactions. With the presented work, we offer an instrument to assess this specific construct and test its explanatory value regarding the evaluation and acceptance of robots.

\subsection{General Self-Efficacy, Technological Self-Efficacy, Its Sub-Concepts and Measures}

Before discussing self-efficacy in the context of human-robot-interaction, we introduce the concept of self-efficacy more generally. Bandura defined self-efficacy as "people's judgments of their capabilities to organize and execute courses of action required to attain designated types of performances. It is concerned not with the skills one has but with judgments of what one can do with whatever skills one possesses" [5, p. 361]. It is important to note that self-efficacy does not equal efficacy. A person can possess the abilities and the power to complete a task successfully with the desired effect, but may not believe that he or she has the power to produce that desired effect. Moreover, self-efficacy should not be mistaken with locus of control or self-esteem, which are related constructs but which describe different aspects of a humans self (cf. [6]).

Self-efficacy is domain specific, meaning people do not have one overarching belief in efficacy, but rather a complex efficacy belief system-"a differentiated set of self-beliefs linked to distinct realms of functioning" [6, p. 207]. Bandura [6] exemplifies that a business executive may have a high sense of organizational efficacy but low parenting efficacy. Even in a field that is assumed to be one domain, such as technology usage, self-efficacy expectations may vary, meaning that a person can exhibit high self-efficacy in one sub-domain (e.g., general computer use), but low self-efficacy in other sub-domains (e.g., smartphone use, programming, interaction with a robot).

Thus, it is no surprise that general self-efficacy scales $[21,60]$ have only limited predictive value when applied to specific domains of functioning (e.g., computer use), because their items do not 
address the situational demands and circumstances of the functional area under consideration. Consequently, scales of perceived self-efficacy must be tailored to the particular domain of functioning that is the object of interest. A number of different instruments have been constructed to address people's efficacy beliefs regarding (new) technology. In addition to a generic technological self-efficacy [51], there are constructs that refer to specific types such as computer self-efficacy $[18,28]$, Internet self-efficacy [65], information technology self-efficacy [62], and smartphone selfefficacy [21]. Comparative studies have shown that these more specialized instruments provide more explanatory value than more general self-efficacy scales [1, 46]. A robot's embodiment, its ability to physically and socially interact with its environment, and the mental image of robots in our society lead to far more complex beliefs about interactions with them, than with computers, tablets, or smartphones. Against this background, we assume that people's perceived self-efficacy in human-robot interaction might differ greatly from those of more general computer use, and, therefore, we see the need to develop a specialized instrument to assess perceived self-efficacy in HRI. This instrument will provide a foundation to assess the prevalence of self-efficacy in HRI at this juncture and its changes in the future, when robots will be used more widely. It will also serve as a criterion to identify user groups that need to strengthen their self-efficacy beliefs, for instance, by specialized trainings. But most importantly, it might contribute to a better understanding of insufficiently explained patterns of evaluations in HRI and, thus, helps to improve the development of new robotic platforms and interaction scenarios.

\subsection{Research Objectives}

The aim of this investigation is to create a German and an English version of a valid and reliable instrument for measuring people's perceived self-efficacy in dealing with robots. Therefore, the first study covers the development of a first version of this instrument including the item generation, their properties and quality, and the analysis of the factorial structure with an explorative factor analysis. In Study 2, we check the revealed factorial structure with a confirmatory factor analysis and optimize the final version of the instrument. In addition, we examine convergent and discriminant validity for the SE-HRI. In a third study, we translated the German version into the English language and tested it on an English sample. Subsequently, we conducted two laboratory studies to test the SE-HRI questionnaire in an experimental setting, and based on the feedback we received, we decided to revise the scale and run another online study as basis for a confirmatory factor analysis on a shorter version of the scale.

\section{STUDY 1-EXPLORATORY FACTORIAL ANALYSIS OF THE GERMAN VERSION}

The first study's aims were to examine the generated items for the SE-HRI Scale in terms of their quality as well as to explore the scale's factorial structure.

\subsection{Item Generation}

Following principles from classic test theory and scale development, it is suggested to start off with a three to four times larger pool of items than the final scale [31]. This is to capture as many characteristics as possible while achieving a high level of reliability and sorting out random errors like misunderstandings or individual interpretations [30]. Thus, the first version of the SE-HRI Scale consists of 50 items that were either adapted from different questionnaires (27 items) or theoretically generated (23 items). A complete list of all 50 items and their original sources can be found in the appendix (cf. Appendix A2). The majority of the adapted items stems from the Computer User Self-Efficacy scale (CUSE) [18], which is a 30-item scale that measures the individual beliefs a person has about their own skills and abilities to successfully use a computer or achieve goals by using it. Because both computers and robots represent some kind of technical 
device that requires technique-related self-efficacy, some similarities can be drawn between these two systems. Therefore, we adapted 15 items of the CUSE so that they match the self-efficacy in human-robot-interaction construct. For example, "I find working with computers very easy" was changed to "I think working with a robot is very easy." According to Bandura's [6] guide for constructing self-efficacy scales, "items should be phrased in terms of can do rather than will do" (p. 308), because "will" is a statement referring to intention rather than referring to capability. However, most people never had any contact with a robot and, therefore, we decided to phrase the items more tentatively, e.g., "I think ..., "I could ...," "I would ...," instead of the more concrete "I can ...," as it was used in the CUSE. We also included three items of the General Self-Efficacy Scale by Jerusalem and Schwarzer [60], which measures the perceived self-efficacy of a person in general. As an example, "If I am in trouble, I can usually think of a solution" has been changed to "If I should solve a problem with the assistance of a robot, I could do that." Further items were adapted from the Technology-Related Self-Concept Questionnaire [42], the questionnaire of the Unified Theory of Acceptance and Use of Technology [UTAUT; 69], and the self-efficacy subscale of the Multi-dimensional Robot Attitude Scale [52]. All other items were generated with reference to Bandura's [6] guide for constructing self-efficacy scales. Bandura emphasizes that "self-efficacy scales must be tailored to activity domains and assess the multifaceted ways in which efficacy beliefs operate within the selected activity domain" (p. 310). Moreover, the scales need to reflect the levels of task demands and gradations of challenges to successful performance. Therefore, "sufficient gradations of difficulties should be built into the efficacy items to avoid ceiling effects" (p. 311). Additionally to the items that we adapted from other questionnaires, we identified different aspects that determine quality of functioning in the domain of human-robot-interaction. First, we focus on participants' beliefs of how easily they could generally (learn to) use or control a robot (example items: "Robots are easy to control." "I could easily learn how to use a robot."). Second, we focused on customization of the robot to one's own needs (example items: "I could teach a robot to complete easy tasks." "I could do easy adjustments on a robot by myself."). Third, we assessed participants' perceived ability to understand cause-and-effect-relations in a robot's behavior (example items: "If I would use a robot, I would always know how and why it behaves like it does." "To me, robots are a book of seven seals."). A fourth aspect was problem-solving with the robot (example items: "If I should solve a problem with the assistance of a robot, I could do that." "I could deploy a robot in a specific way to save time."). And the last aspect we identified was that of troubleshooting (example items: "If a robot is doing something wrong, I could find a way to change its behavior." "If there is a problem with a robot, I would try to solve it by myself before asking somebody for help."). For these five aspects, we made sure to generate items that reflect different gradations of challenges. For instance, a low gradation for general use would be "It is easy to use a robot." while a high gradation would be, "When dealing with robots, I could exhaust the full potential." Similarly, a low gradation of challenge for customization would be "I could do easy adjustments on a robot by myself." and a high gradation would be "I could program a robot."

\subsection{Participants}

Participants for this first study were recruited via Internet advertisement on several social networking sites and online discussion boards. The majority of the 201 participants (134 male; 2 not specified) were students $(60.2 \%)$ or employees $(35.3 \%)$. The remaining part stated to be selfemployed $(2.5 \%)$ or did not indicate their status (2.5\%). Age ranged between 19 and 60 years $(M=$ $27.02 ; S D=7.40)$. The majority of the participants used computers on a regular basis for work $(94 \%)$ or in their free time (93\%). More than a third of the participants (40.4\%) already had previous contact with a robot, for instance, with vacuum robots, with robots in museums, or in programming classes in high school. 
Table 1. Empirical Eigenvalues of the PCA (with Varimax Rotation) of the Robot Self-Efficacy Rating (33 Items) Compared with Eigenvalues Obtained by Parallel Analyses [37]

\begin{tabular}{ccccc}
\hline Factor & $\begin{array}{c}\text { Eigenvalue } \\
\text { (empirical) }\end{array}$ & $\begin{array}{c}\text { Eigenvalue } \\
\text { (parallel analysis) }\end{array}$ & Variance in $\%$ & $\begin{array}{c}\text { Cumulative } \\
\text { Variance in } \%\end{array}$ \\
\hline 1 & 17.31 & 1.93 & 47.01 & 47.01 \\
2 & 2.61 & 1.80 & 6.27 & 53.28 \\
3 & 1.37 & 1.73 & 2.84 & 56.12 \\
4 & 1.17 & 1.64 & 2.03 & 58.15 \\
5 & 1.02 & 1.57 & 1.65 & 59.80 \\
6 & .93 & 1.50 & & \\
7 & .89 & 1.44 & & \\
8 & .72 & 1.38 & & \\
9 & .70 & 1.32 & & \\
10 & .64 & 1.26 & & \\
\hline
\end{tabular}

\subsection{Instruments}

Participants filled in the first version of the SE-HRI Scale, as described above (cf. Table 2 in appendix for full list of items). The items were rated on a 6-point Likert scale from 1 ("strongly disagree") to 6 ("strongly agree").

\subsection{Results and Discussion}

In the following, we refer to single items according to the label they received during item generation (cf. Table 2 in appendix for full list of items with labels). The item analysis revealed no saliences except for one item ("I usually try out new technical devices before taking a look at the manual”). This item was excluded from further calculations due to insufficient item discrimination (Item-total-correlation $=.132)$. All 201 cases were used in an exploratory factor analysis $(\mathrm{EFA})$ to expose underlying latent variables behind the remaining 49 items. The Kaiser-Meyer-Olkin (KMO) [43] measure verified the sampling adequacy for the analysis, KMO = .947 ("superb" according to [40]), and all KMO values for individual items were $>.68$, which is well above the acceptable limit of .5 [33]. Bartlett's test of sphericity indicated that correlations between items were sufficiently large for EFA $\left(\chi^{2}(200)=7482.502, p<.001 ;[8]\right)$. Seven components had eigenvalues over Kaiser's criterion of 1 [44] and, in combination, explained $44.78 \%$ of variance. The scree test [19] showed an inflexion that would justify retaining only two components. However, since Kaiser's criterion and scree test are affected with the risk of overfactoring [32], an additional parallel analysis, according to Horn [37], was conducted. Parallel analysis identified and suggested two factors whose empirical eigenvalues based on the sampling data were higher than the eigenvalues that can be expected to be obtained from completely random data. Given that two of the methods for factor extraction indicated two components, this was the number of components that were retained in the next step.

Principal component analysis (PCA) with promax rotation was chosen as the extraction algorithm as recommended by Ferguson and Cox [32]. PCA resulted in two factors. By analyzing the factor loadings of each item, 14 items with main factor loadings $<.5$ and second factor loadings $>.3$ were excluded (see Appendix A3, Table 3). The remaining construct included 36 items with 30 items on the first factor. To validate this structure, two more iterations of EFA were conducted in which three more items were excluded due to low factor loadings. Table 1 shows the empirical and calculated eigenvalues according to the parallel analysis in the third iteration of EFA. PCA 
Table 2. Summary of Items, Factor Loadings, and Communalities for Promax Two-factor Solution for Robot Self-Efficacy (N=201)

\begin{tabular}{|c|c|c|c|}
\hline Items & Factor 1 Self-Efficacy & Factor 2 Loss of Control & Communality \\
\hline SE-HRI46 & .876 & -.071 & .710 \\
\hline SE-HRI32 & .848 & .024 & .739 \\
\hline SE-HRI21 & .827 & -.059 & .639 \\
\hline SE-HRI29 & .818 & -.132 & .579 \\
\hline SE-HRI44 & .804 & -.168 & .540 \\
\hline SE-HRI43 & .803 & -.021 & .628 \\
\hline SE-HRI30 & .776 & -.022 & .586 \\
\hline SE-HRI24 & .764 & .100 & .670 \\
\hline SE-HRI11 & .754 & -.037 & .542 \\
\hline SE-HRI23 & .748 & .012 & .568 \\
\hline SE-HRI22 & .731 & .013 & .544 \\
\hline SE-HRI31 & .727 & .066 & .580 \\
\hline SE-HRI41 & .719 & .008 & .523 \\
\hline SE-HRI26 & .711 & -.134 & .429 \\
\hline SE-HRI12 & .710 & -.047 & .474 \\
\hline SE-HRI50 & .709 & .079 & .563 \\
\hline SE-HRI25 & .707 & .123 & .601 \\
\hline SE-HRI38 & .702 & .054 & .534 \\
\hline SE-HRI19 & .699 & .075 & .546 \\
\hline SE-HRI48 & .695 & .077 & .542 \\
\hline SE-HRI27 & .671 & -.096 & .396 \\
\hline SE-HRI45 & .660 & .107 & .516 \\
\hline SE-HRI02 & .651 & -.020 & .411 \\
\hline SE-HRI14 & .638 & .021 & .420 \\
\hline SE-HRI05 & .618 & .180 & .524 \\
\hline SE-HRI15 & .601 & .010 & .366 \\
\hline SE-HRI18 & .592 & .248 & .558 \\
\hline SE-HRI49 & .577 & .066 & .376 \\
\hline SE-HRI01 & .570 & -.007 & .320 \\
\hline SE-HRI36 & .114 & .710 & .597 \\
\hline SE-HRI47 & .105 & .683 & .548 \\
\hline SE-HRI40 & -.041 & .860 & .706 \\
\hline SE-HRI39 & -.239 & .939 & .717 \\
\hline Eigenvalue & 17.31 & 2.98 & \\
\hline$\%$ of Variance & $47.01 \%$ & $6.27 \%$ & \\
\hline Cronbach's $\alpha$ & .945 & .864 & \\
\hline
\end{tabular}

Note: Item labels refer to the initial list of 50 items, cf. Table 2 in appendix.

showed satisfying factor loadings $(>.400$; cf. $[63,67])$ for all items. The final factor loadings and communalities are displayed in the component matrix in Table 2. Thus, the two resulting factors of the PCA are: perceived self-efficacy with 29 items like "I could use a robot in daily life." or "I could adjust a robot according to my individual preferences." and loss of control with four items like "I do not have any influence on what a robot is doing" or "A robot does what it wants." The cut-down scale produced very high internal consistencies with Cronbach's alphas of .97 as well 
as high inter-correlations of items, which suggests redundancy within the scale and narrowness of the scale $[13,14]$. Although not many, there are some items within the scale that seem to be formulated alike or which tackle similar tasks or beliefs (e.g., "It is easy to use a robot." and "I could easily learn how to use a robot."). According to Kline [45] "if one constructs items that are virtually paraphrases of each other, the results would be high internal consistency and very low validity" (p.3). As a result, we decided to keep the scale as it is, but we will be open to possibly further reducing the number of items in subsequent analyses.

\section{STUDY 2. CONFIRMATORY FACTOR ANALYSIS OF GERMAN VERSION}

The second study's purpose was to validate the previously found item structure and the extracted two-factorial design. Therefore, a confirmatory factor analysis (CFA) was performed on a second sample. Additionally, we followed the method of destructive testing by Anderson and Anderson [2] with analyses of convergent and discriminant validity. Bandura, Adams, and Beyer [7] note that past self-efficacy-related experiences regarding different domains may generalize and, therefore, can be transferred to other areas. Hence, we hypothesize that general as well as computeruser self-efficacy will be correlated positively with the SE-HRI Scale. Further, Celik and Yesilyurt [20] found that attitudes toward technology positively affect participants' perceived computer self-efficacy. Therefore, we hypothesize that negative attitudes toward robots will be negatively correlated with participants' self-efficacy in HRI. For examining discriminant validity, we chose to include people's tendency to affiliate and bond with others. We assume that perceived self-efficacy in HRI can be positively influenced by experience, and that increases in self-efficacy perceptions can explain individual differences in the evaluations of the robot. Regarding the latter, it is also possible that evaluations are positively influenced by people's need to affiliate and bond with others and their desire to make others like them. Since the interaction with the robot might satisfy needs for belongingness on a very basic level, the satisfaction of this need might result in more positive evaluations. However, it is important to note that fulfilling belongingness needs is distinct from competency acquisition, although both concepts might be relevant for evaluations in human-robot interactions. Hence, we hypothesize that people's tendency to affiliate with others will not correlate with perceived self-efficacy in HRI.

\subsection{Participants}

For this second study, 450 participants (288 female; 4 not specified) were recruited via local advertisement at the University of Duisburg-Essen and advertisements on social networking sites and online discussion boards. It is possible that there were overlaps in participants to Study 1. However, participants knew the purpose of the studies from the beginning and remembering the items would most likely not influence their ratings. As incentive, every attendant had the chance to win Amazon vouchers of a total value of EUR 600. The majority of the participants were students $(72 \%)$, or employees $(20.2 \%)$, while $2.2 \%$ were trainees, $7 \%$ self-employed, and $4.4 \%$ did not specify their occupation. Age ranged between 18 and 59 years $(M=25.15, S D=6.66)$. About a third $(36.2 \%)$ of the participants already had previous contact with a robot.

\subsection{Instruments}

To validate the two-factor structure, all participants had to complete the refined version of the Self-Efficacy in HRI Scale that resulted from Study 1. Therefore, the above-mentioned convergent and discriminant constructs were operationalized by different parts of various questionnaires (cf. Table 3 for an overview). As convergent constructs, we surveyed the above-mentioned general self-efficacy (GSE; [60]; Cronbach's $\alpha=.868$ ), CUSE ([18]; Cronbach's $\alpha=.943$ ), and participants' negative attitudes toward robots (NARS; [53]; overall: Cronbach's $\alpha=.863$; subscale interaction: 
Table 3. List of Assessed Convergent and Divergent Instruments

\begin{tabular}{lll}
\hline & Instrument & Author \\
\hline Convergent & KUT-Technique-related locus of control (ger.: & Beier, 1999 [10] \\
& Kontrollüberzeugung im Umgang mit Technik) & \\
& GSE-General Self-Efficacy & Schwarzer and Jerusalem, 1995 [60] \\
& CUSE-Computer User Self-Efficacy Scale & Cassidy and Eachus, 2002 [18] \\
& NARS-Negative Attitudes toward Robots Scale & Nomura et al., 2006 [53] \\
\hline Discriminant & ISEL-Interpersonal Support Evaluation List & Cohen and Hoberman, 1983 [24] \\
& ASI-Affinity Seeking Instrument & Bell et al., 1987 [11] \\
\hline
\end{tabular}

Cronbach's $\alpha=.698$; subscale social: Cronbach's $\alpha=.764$; subscale emotional: Cronbach's $\alpha=$ .638). In addition, participants' technology-related locus of control was measured using an instrument by Beier [10] (KUT; Cronbach's $\alpha=.787$ ). The belonging subscale of the short Interpersonal Support Evaluation List (ISEL-12; [25]; Cronbach's $\alpha=.745$ ) was used to examine the Self-Effiacy in HRI's discriminant relation to belongingness as well as the Affinity Seeking Instrument (ASI; [11]; overall scale: Cronbach's $\alpha=.848$, subscale affinity seeking competence: Cronbach's $\alpha=.870$, subscale strategic performance: Cronbach's $\alpha=.795)$. The ASI measures to which extent people attempt to get others to like and feel positive toward them on a 7-point Likert scale from "very strongly disagree" to "very strongly agree."

Since the questionnaire shall be used in studies also involving technologically unexperienced elderly users, we further invited six older adults in order to identify potential wording-effects or other comprehension difficulties. Their comments were used to inform textual and content decisions on single items.

\subsection{Statistical Analyses}

The CFA was performed with the statistical modeling program Mplus (https://www.statmodel. com; version 6.12). Due to positive skewness, the assumption of multivariate normality was not achieved for any of the questionnaire items. Since the items were assessed using a 6-point Likert scale, the data can be considered as continuous [49]. Therefore, the Satorra-Bentler chi-square correction [58] (MLM estimator in MPlus), which is robust to non-normality, was used to perform the CFA. Following Schermelleh-Engel, Moosbrugger, and Müller [59], Brown [15], and Hu [39], the subsequent fit-indices and well-established cut-off scores were used to verify the model fit: Absolute fit indices like the $\chi^{2}$-index and the standardized root mean square residual (SRMR; <.08), the parsimony fit-index root mean square error of approximation (RMSEA; <.08), as well as the comparative fit index (CFI; >.90). Due to the $\chi^{2}$ statistics' sensitivity for sample sizes, the $\chi^{2}$ to degrees of freedom ratio $\left(\chi^{2} / \mathrm{df}\right)$ was used to estimate the general model fit. Commonly used reference values are a $\chi^{2} / \mathrm{df}$ ratio of $<2$ for a good model fit and a ratio of $<3$ for an acceptable model fit [17]. All analyses regarding the construct validity were conducted using SPSS for Windows (version 22.0; IBM SPSS Statistics).

\subsection{Results and Discussion}

3.4.1 Confirmatory Factor Analysis. The basic Self-Efficacy in HRI Scale had excellent internal consistency with Cronbach's $\alpha=.94$ for the scale overall, Cronbach's $\alpha=.96$ for perceived selfefficacy, and Cronbach's $\alpha=.88$ for loss of control. The first CFA testing the basic questionnaire yielded a bad model-fit with $\chi^{2} / \mathrm{df}$-ratio of 5.21 and poor values for the other fit-indices: RMSEA = $.097, \mathrm{CFI}=.84$, and SRMR $=.055$. Therefore, further analyses focused on standardized residual 
Table 4. Multiple Hierarchical Regression Analyses of the German and (English) SE-HRI on the Respective Convergent Constructs

\begin{tabular}{lcccc}
\hline & $R^{2}$ & $\Delta R^{2}$ & $\Delta F$ & $p$ \\
\hline Computer user self-efficacy $(\mathrm{n}=450)$ & & & & \\
self-efficacy & .261 & & 158.59 & $<.001$ \\
loss of control & .281 & .019 & 12.11 & .001 \\
Negative Attitudes toward Robots $(\mathrm{n}=445)$ & & & & \\
self-efficacy & .274 & & 167.10 & $<.001$ \\
loss of control & .292 & .018 & 11.35 & .001 \\
$\quad$ Social & & & & \\
$\quad$ self-efficacy & .118 & & 59.49 & $<.001$ \\
loss of control & .135 & .017 & 8.74 & .003 \\
Emotion & & & & \\
self-efficacy & .192 & & 105.38 & $<.001$ \\
$\quad$ loss of control & .192 & $<.001$ & .21 & .645 \\
Interaction & & & & \\
self-efficacy & .291 & & 185.95 & $<.001$ \\
$\quad$ loss of control & .320 & .032 & 20.60 & $<.001$ \\
General self-efficacy (n=450) & & & & \\
self-efficacy & .081 & & 39.50 & $<.001$ \\
loss of control & .086 & .005 & 2.26 & .133 \\
Technology-related locus of control (n $=450)$ & & & & \\
self-efficacy & .245 & & 145.29 & .000 \\
loss of control & .258 & .013 & 7.754 & .006 \\
\hline
\end{tabular}

loadings, item-correlations, as well as on suggestions regarding item formulation based on the qualitative interviews (see Appendix A3, Table 3 for excluded items and explanations). Respectively, eight further items were excluded, resulting in a construct consisting of 26 items with 23 items loading on factor one, perceived self-efficacy (Cronbach's $\alpha=.97$ ), and three items on factor two, loss of control (Cronbach's $\alpha=.91$ ).

A general recommendation for scale development suggest that with as few as three items, adequate internal consistency reliabilities can be obtained [29], but at least four items per subscale are needed to test the homogeneity of items within each latent construct [cf. 12,36]. This called into question whether to stick with the two factor solution, especially because the results of the CFA also indicated only an acceptable model-fit for the two factor solution $\left(\chi^{2} / \mathrm{df}\right.$-ratio of 2.94 , RMSEA $=.066, \mathrm{CFI}=.93$, SRMR $=.045)$. In addition, we explored the incremental validity using multiple hierarchical regression analyses for analyzing the specific predictive value of each factor of the SE-HRI Scale regarding the convergent validation constructs (e.g., general self-efficacy and computer user self-efficacy). We found that perceived self-efficacy had the strongest predictive value and that adding the factor loss of control as a second predictor showed only very small changes in $R^{2}$ (e.g., a change in $R^{2}$ from .261 to .281 for computer user self-efficacy, Table 4). Given these results and for the sake of test efficiency, we decided to dismiss the two-factorial solution and further explored a one-factorial solution. The next CFA based on the one factor model with 23 items showed a bad model-fit with a $\chi^{2} / \mathrm{df}$-ratio of 3.19 , RMSEA $=.070, \mathrm{CFI}=.93$, and SRMR $=$ .036. Hence, we conducted further analyses focused on standardized residual loadings, itemcorrelations, as well as on qualitative analyses of the item formulation gained from the qualitative 
Table 5. Correlations ( $r$ ) Between the German (English) SE-HRI with Convergent Constructs

\begin{tabular}{lcc}
\hline & German SE-HRI & English SE-HRI \\
\hline CUSE $(\mathrm{n}=450(209))$ & $.500^{* *}$ & $.489^{* *}$ \\
KUT $(\mathrm{n}=450(209))$ & $.492^{* *}$ & $.510^{* *}$ \\
GSE $(\mathrm{n}=450(209))$ & $.271^{* *}$ & $.298^{* *}$ \\
NARS $(\mathrm{n}=445(207))$ & $-.517^{* *}$ & $-.540^{* *}$ \\
Social & $-.341^{* *}$ & $-.353^{* *}$ \\
Emotions & $-.431^{* *}$ & $-.497^{* *}$ \\
Interaction & $-.534^{* *}$ & $-.513^{* *}$ \\
\hline
\end{tabular}

${ }^{* *} p<.01$.

Table 6. Correlations ( $r$ ) Between the German and (English) SE-HRI with Discriminant Constructs

\begin{tabular}{lcc}
\hline & German SE-HRI & English SE-HRI \\
\hline ISEL $(\mathrm{n}=450(209))$ & .025 & .012 \\
ASI $(\mathrm{n}=450(209))$ & .089 & $.143^{*}$ \\
Affinity-Seeking Comp. & .075 & $.142^{*}$ \\
Strategic Performance & .063 & .093 \\
\hline
\end{tabular}

${ }^{*} p<.05$.

interviews. We identified five items that were excluded from further analysis (see Appendix A3, Table 3 for items and explanations). The final CFA based on the one factor model with 18 items showed a good model-fit with a $\chi^{2} / \mathrm{df}$-ratio of 2.98 , RMSEA $=.066, \mathrm{CFI}=.95$, and SRMR $=.029$.

3.4.2 Construct Validity. To check for construct validity, constructs that are assumed to be either convergent or discriminant to the construct of Self-Efficacy in HRI were correlated with the scores of the SE-HRI. As predicted, all convergent constructs were significantly correlated with SEHRI (cf. Table 5). The participants' computer user self-efficacy, technology-related locus of control, and their general self-efficacy were positively correlated with their overall self-efficacy in dealing with robots. As assumed, the participant's negative attitudes toward robots were negatively correlated with their overall robot self-efficacy, which seems conclusive: Participants with strong negative attitudes toward robots seem to have lower beliefs about their capabilities in dealing with robots. Also, as expected, the two discriminant constructs belonging (ISEL) and affinity seeking were not correlated with the SE-HRI Scale at all (Table 6). Overall, these findings demonstrate that the SE-HRI Scale has a good construct validity.

\section{STUDY 3-CONFIRMATORY FACTOR ANALYSIS OF ENGLISH VERSION}

In parallel to the German version of the Robot Self-Efficacy Scale, we also created an English version in collaboration with an American native speaker. The 33 items, which were extracted via the EFA in Study 1, were translated into English. To evaluate the accuracy of the translation, we used the method of back-translation and let two previously not involved associates translate the English items back into the German language. The meanings of all back-translated items corresponded to the ones of the original items. Only a few minor wording issues were edited in consultation with the native speaker. To validate the English version independently, we conducted another survey in exactly the same manner (as in Study 2) with an English sample. 


\subsection{Participants}

During the survey period, 209 (104 male; 105 female) participants were recruited via internet ads on social network sites and online discussion boards. As incentive, the participants also had the chance to win Amazon vouchers of a total value of US\$600. The greater part of the sample consisted either of students $(59.8 \%)$ or employees $(28.7 \%)$. The rest were trainees $(3.3 \%)$, self-employed $(2.9 \%)$, or not specified (5.3\%). The age ranged between 16 and 69 with an average of $M=26.48(S D=9.11)$. Nearly half (45\%) already had contact with a robot once, for instance, in programming classes at high school, in museums, or at work.

\subsection{Instruments}

In line with the survey in Study 2, we used the same instruments and measures in this study in the English language. Convergent constructs were the GSE (Cronbach's $\alpha=.876$ ), CUSE (Cronbach's $\alpha=.947$ ), participants' NARS (overall: Cronbach's $\alpha=.873$; subscales: emotion Cronbach's $\alpha=.741$, social Cronbach's $\alpha=.760$, interaction Cronbach's $\alpha=.811$ ), and participants' KUT (Cronbach's $\alpha=.779$ ). Discriminant constructs were the belonging subscale of the ISEL (Cronbach's $\alpha=.643$ ) and affinity seeking (ASI, overall: Cronbach's $\alpha=.862$, affinity seeking competence: Cronbach's $\alpha=.854$, strategic performance: Cronbach's $\alpha=.793$ ).

\subsection{Statistical Analyses}

To evaluate the English version of the SE-HRI, we used the final model, which we previously extracted in Study 2 in a CFA. Like the German sample, the English sample also did not meet the assumption of multivariate normality for any item, due to positive skewness. Hence, the robust Satorra-Bentler chi-square correction [58] (MLM estimator in MPlus) was used to perform the CFA. The same fit-indices and cut-off scores as in Study 2 were used.

\subsection{Results and Discussion}

4.4.1 Confirmatory Factor Analysis. The confirmatory factor analysis revealed that the final model from Study 2 also fits the English sample. The SRMR indicated a good model-fit with SRMR = $.045, \chi^{2} /$ df-ratio $=2.27$, RMSEA $=.078$, and CFI $=.929$.

4.4.2 Construct Validity. To further examine the construct validity of the English version, convergent and divergent constructs were correlated with the scores of the SE-HRI. As expected, nearly all convergent constructs showed significant small or medium correlations with the SEHRI comparable to Study 2 (cf. Table 4). Regarding the divergent constructs, weak but significant correlations were obtained between the SE-HRI and the overall affinity seeking, and the sub-scale affinity seeking competence. Visual examinations of the scatter plots revealed that the rather small correlations coefficients [23, 47] might not reflect linear relationships [48] (cf. Appendix A4, Figure 1). All other correlations were not significant (cf. Table 5).

\section{STUDY 4-EXPERIMENTAL STUDY ON SELF-EFFICACY IN HRI WITH DIFFERENT AGE GROUPS}

The main focus of this study was to explore whether perceived self-efficacy in HRI can be positively influenced by enactive attainment or, in other words, the experience of mastery in an interaction with a robot [5, 6], as it was shown with computers [66]. Further, we investigated whether more active and involving interactions have a greater effect than more basic interactions, and whether the change in self-efficacy beliefs in HRI mediates the evaluation of the robot itself. Even though 


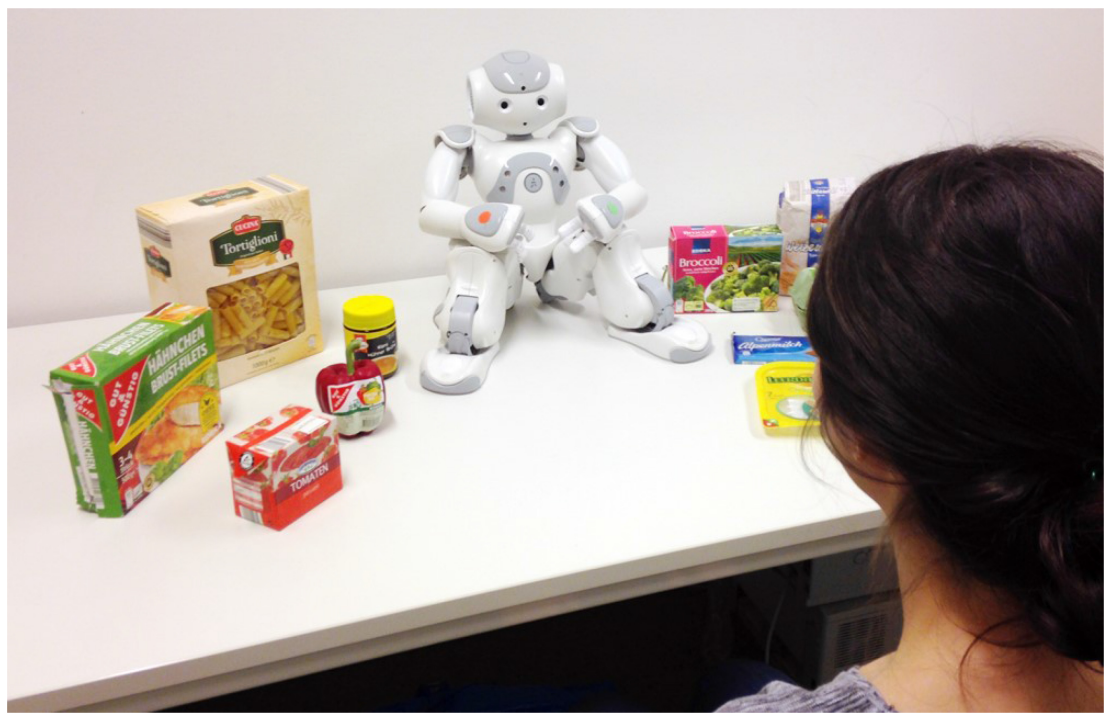

Fig. 1. Setup for the training and social interaction.

the study was not exclusively designed for the purpose of scale development, it still puts the SEHRI Scale in use as a mediator in an experimental setting and, thus, provides information on its functionality. Nevertheless, this study has already been presented in detail in another publication and would go beyond the scope of this article. Hence, we will only provide a brief summary of the study and present the findings that are important for the evaluation of the scale. Please refer to the corresponding publication for more details [3].

\subsection{Method}

The study was conducted with a student sample and was partly repeated with a sample of seniors (with a slight variation in conditions), to also address age-related differences. The elementary concept was a $3 \times 3$ mixed design with three experimental groups and three repeated measures on participants' self-reported perceived self-efficacy in HRI. Participants in all three experimental groups engaged in an actual social interaction with the Nao robot by discussing foods and recipes. Prior to this social interaction, participants either had

- no direct contact (read a fact sheet about the robot; control group),

- basic contact (showing objects to the robot) or

- active contact (training the robot to categorize objects) to the robot.

For the study involving senior participants, we followed a slightly different research question, exploring different mechanisms on how to adapt a robot and, thus, replaced Condition (b) with indirect active contact (training the robot through a programmer).

\subsection{Participants, Procedure, and Measures}

The student sample consisted of 60 (38 female, 22 male) participants who were recruited on campus. They were aged between 18 and 39 years $(M=22.42, S D=4.08)$. The senior sample consisted of 60 volunteers ( 35 female, 25 male) aged between 60 and 84 years $(M=68.02, S D=5.38)$ who were recruited using flyers in pharmacies, bakeries, bookstores, and recreation centers for seniors. Some participants were recruited online via Facebook. In total, the participants completed the SE-HRI 
Table 7. Repeated Measures ANOVAs for Experimental Conditions with Dependent Factor Perceived Self-Efficacy

\begin{tabular}{llccccccccccccc}
\hline & & \multicolumn{1}{c}{$\mathrm{T} 1$} & \multicolumn{1}{c}{$\mathrm{T} 2$} & $\mathrm{~T} 3$ & \multicolumn{4}{c}{$\mathrm{T} 1<\mathrm{T} 2$} & $\mathrm{~T} 2<\mathrm{T} 3$ & $\mathrm{~T} 1<\mathrm{T} 3$ \\
\cline { 2 - 14 } & & $\mu$ & $S D$ & $\mu$ & $S D$ & $\mu$ & $S D$ & $F$ & $\eta^{2}$ & $p$ & $N$ & $p$ & $P$ & $p$ \\
\hline Study 1 & Total & 3.02 & 0.93 & 3.66 & 0.95 & 3.84 & 1.06 & 36.5 & 0.38 & $<.001$ & 60 & $<.001$ & 0.076 & $<.001$ \\
Students & Control & 3.31 & 0.94 & 3.43 & 1.12 & 3.55 & 1.3 & 1.19 & 0.06 & 0.3 & 20 & 0.498 & 1.00 & 0.725 \\
n=60 & Basic Int. & 2.7 & 0.83 & 3.79 & 0.73 & 4.05 & 0.92 & 32.9 & 0.63 & $\boldsymbol{< . 0 0 1}$ & 20 & $<.001$ & 0.46 & $<.001$ \\
& Training & 3.04 & 0.96 & 3.74 & 0.97 & 3.93 & 0.89 & 21.1 & 0.53 & $<.001$ & 20 & $<.001$ & 0.074 & $<.001$ \\
\hline Study 2 & Total & 3.46 & 1.31 & 3.46 & 1.43 & 3.7 & 1.42 & 3.95 & 0.06 & $\mathbf{0 . 0 3}$ & 60 & 1 & $\mathbf{0 . 0 0 6}$ & 0.088 \\
Seniors & Control & 3.58 & 1.19 & 3.63 & 1.61 & 3.98 & 1.46 & 3.72 & 0.16 & $\mathbf{0 . 0 3}$ & 20 & 1 & $\mathbf{0 . 0 3 6}$ & 0.081 \\
n=60 & Programmer & 3.43 & 1.31 & 3.16 & 1.16 & 3.45 & 1.2 & 1.74 & 0.08 & 0.19 & 20 & 0.53 & 0.334 & 1.00 \\
& Training & 3.37 & 1.47 & 3.58 & 1.49 & 3.69 & 1.57 & 1.46 & 0.07 & 0.24 & 20 & 0.941 & 0.744 & 0.606 \\
\hline
\end{tabular}

Scale three times: upon arrival (T1), after the manipulation (T2) (fact sheet; basic contact/indirect contact; active contact), and after the social interaction (T3). At measuring point T3, participants also completed further questionnaires, including four subscales of the Godspeed Questionnaire (Anthropomorphism, Animacy, Liking, Perceived Intelligence)[9], a semantic differential with 25 bi-polar items that are rated on a 5-point scale.

\subsection{Results and Discussion}

5.3.1 Results Student Sample. Student sample: We conducted split-plot ANOVAs with the group factor experimental condition and repeated measures for perceived self-efficacy. We found a main effect for the repeated measures indicating that self-efficacy increased over the three measuring points (Table 7) and an interaction effect of the repeated measures with the experimental condition $\left(F(38,2)=7.32, p<.001, \eta^{2}=.204\right)$. Three separate ANOVAs were calculated to further explore these effects showing that interaction, in general, regardless of whether this interaction is basic or active, leads to higher self-efficacy (cf. [3]). In addition, we assumed that changes in perceived self-efficacy predict evaluations of the robot, with greater increases leading to more positive evaluations. We calculated self-efficacy deltas (T3-T1) and conducted regression analyses with the self-efficacy deltas as predictor. We found significant regression models for Anthropomorphism, Animacy, Perceived Intelligence, and Likability, demonstrating that individual increases in selfefficacy result in more positive evaluations of the robot.

5.3.2 Results Senior Sample. The same analyses were repeated with the senior sample and resulted in a main effect for the repeated measures on perceived self-efficacy, indicating that selfefficacy, in general, increased over the three measuring points (cf. Table 7). However, there was no effect for the experimental condition. The three separate ANOVAs revealed that, in contrast to the student sample, reading a fact sheet about the robot led to higher self-efficacy perceptions. Also for the seniors, we calculated self-efficacy deltas by subtracting perceived self-efficacy scores at T1 of those scores at T3 and conducted regression analyses with the self-efficacy deltas as predictor and the dependent variables from the Godspeed Questionnaire. No significant regression models emerged.

5.3.3 Discussion. In summary, the interaction with the robot indeed led to increased selfefficacy and this individual increase in self-efficacy perceptions predicted positive evaluations of the robot and interactions for the student sample. The fact that interacting with a robot actually leads to increased scores on the SE-HRI Scale is another indicator for good construct validity. 
Moreover, showing the predictive characteristic of the SE-HRI Scale emphasizes its explanatory value as moderating or mediating variables in HRI studies. To our surprise, the findings of the first study could not be replicated with the senior sample. We discussed implications of these findings in our earlier work [3], for instance, that regarding self-efficacy in HRI, seniors might benefit more from vicarious experience or other specialized trainings instead of mastery experiences. However, it is also possible that the unexpected results are due to limitations of the study and the design of the scale. Compared to the students who are familiar with study participation, answering schemes of scales and the like, we observed that senior participants had problems understanding the instructions, which resulted in attempts to appear coherent in their answers, the tendency to extreme responding or other biases (cf. [3] for more details).

We concluded that the instructions should be made more explicit to the seniors: participants should know they have to indicate their current (not imagined) level of self-efficacy, that selfefficacy might change during the course of the experiment and, hence, that they do not need to be consistent in their answers. When using our scale as a mediator "in the sense that individual increases in self-efficacy predict evaluations," scholars will need to administer the scale at least twice. Regarding unexperienced study participants, it would be beneficial to use a shorter version in order to not over-stress patience and to keep participants motivated.

\section{STUDY 5. CONFIRMATORY FACTOR ANALYSIS OF SHORT VERSION}

Based on the feedback we received during the two experimental studies, we developed a short version of the scale and set up another online survey to validate this shorter version. We performed EFAs on the data sets from Study 2 and 3 with the 18 items version of the scale. Although item discrimination and item factor loadings were good for all items, we concentrated on the weakest items and omitted five items with the lowest item discrimination $(<.657)$ and factor loadings $(<.674)$ with the positive effect that the explained variance minimally improved with every omitted item (see Appendix A3, Table 3). We then calculated the model fits on both samples (German and English) and reviewed item correlations and suggestions for modifications, which led us to omit three further items (see Appendix A3, Table 3). The remaining 10 items were used in the following online survey.

We also revised the instructions for the scale. As Bandura points out, "it is easy for people to imagine themselves to be fully efficacious in some hypothetical future" [6, p. 313]. Indeed, we observed this answering behavior in quite a number of our senior participants in Study 4. Bandura [6] suggests to clearly state that evaluations should be based on their current status or constitution and to provide an example item [cf. 6, p. 313]. Hence, we changed the instruction to: "Below you will find several statements regarding your feelings about robots. You should evaluate these statements based on your current constitution. It is not about your potential skills in the future. Example: 'It would be easy for me to lift a 300lb dumbbell.' When evaluating this statement, you should do so based on your current strength, and not based on your potential strength in the future, when you intend to train for it."

As a final improvement, we decided to rework the answering scheme. Initially, we followed the approach of other scholars designing self-efficacy scales by using a Likert scale (e.g., for general self-efficacy, Schwarzer \& Jerusalem [60] used a 4-point Likert scale). However, Bandura suggests that scales that use only a few steps should be avoided and argues that "people usually avoid the extreme positions so a scale with only a few steps may, in actual use, shrink to one or two points. Including too few steps loses differentiating information because people who use the same response category may differ if intermediate steps were included" [6, p. 312]. Bandura suggest to use a rather wide range within the measure, either a ten-point Likert scale or better people should 
report strength of their efficacy beliefs with a number between 0 and 100. In our study, we used a slider ranging from 0 to 100 with the ends "cannot do" and "certainly can do."

\subsection{Participants}

For the CFA of the short version of the scale, 196 participants (101 male; 95 female) were recruited via crowdflower (www.crowdflower.com) and received thirty cents USD/Euro for participation. The questionnaire was accessible to crowdflower contributors from the US, Canada, and Great Britain for the English sample $(n=83)$ and Germany, Switzerland, and Austria for the German sample $(\mathrm{n}=113)$. The greater part of the sample consisted either of students $(16.3 \%)$ or employees $(47.4 \%)$. The rest were trainees $(4.6 \%)$, self-employed $(14.3 \%)$, or not specified (17.3\%). The age ranged between 18 and 82 with an average of $\mathrm{M}=36.91(S D=13.97)$. Twenty-seven percent already had contact with a robot once, for instance, in programming classes at high school, in museums, or at work.

\subsection{Instruments}

In line with the survey in Study 2 and 3, we used the same instruments and measures in this final study. Convergent constructs were again the GSE (Cronbach's $\alpha=.864$ ), CUSE (Cronbach's $\alpha=$ .957), participants' NARS (overall: Cronbach's $\alpha=.870$; subscales: emotion Cronbach's $\alpha=.717$, social Cronbach's $\alpha=.747$, interaction Cronbach's $\alpha=.843$ ), and participants' KUT (Cronbach's $\alpha=$.795). Discriminant constructs were the belonging subscale of the ISEL (Cronbach's $\alpha=.883$ ) and affinity seeking (ASI, overall: Cronbach's $\alpha=.846$, affinity seeking competence: Cronbach's $\alpha=.860$, strategic performance: Cronbach's $\alpha=.787$ ).

Instead of the 18-item version of the SE-HRI, we administered the 10-item short version as described above, including the new answering scheme and instructions (Cronbach's $\alpha=.941$ ). Moreover, we presented all 10 items again, asking participants whether they feel this is an easy or difficult task (e.g., "I could get a robot to perform a specific task." - "I find this task... easy/difficult"). This was to ensure that efficacy in HRI "is measured against levels of task demands that represent gradations of challenges or impediments to successful performance” in HRI [6, p. 311].

\subsection{Results and Discussion}

6.3.1 Confirmatory Factor Analysis. To evaluate the short version of the SE-HRI, we used the 10 items in a CFA. Like in the previous online surveys, the sample did not meet the assumption of multivariate normality for any item, due to positive skewness. Hence, the robust Satorra-Bentler chi-square correction [58] (MLM estimator in MPlus) was used to perform the CFA. The same fit-indices and cut-off scores were used in this analysis.

The confirmatory factor analysis revealed that the 10-item model fits the German sample: The SRMR indicated a good model-fit with SRMR $=.038, \chi^{2} / \mathrm{df}$-ratio $=1.48, \mathrm{RMSEA}=.065$, and CFI $=$ .973. For the English sample, the model achieved an acceptable model fit with SRMR $=.059, \chi^{2} / \mathrm{df}-$ ratio $=1.97$, RMSEA $=.108, \mathrm{CFI}=.942$.

6.3.2 Construct Validity. To examine the construct validity of the scale, convergent and divergent constructs were correlated with the scores of the SE-HRI. As in Study 2 and 3, all convergent constructs showed significant small or medium correlations with the SE-HRI comparable (cf. Table 8). Yet, the correlations were slightly smaller than in the previous studies, which, most likely, is a methodological artifact resulting from the change in the answering theme and the varying demographic data (e.g., mean age and occupation). Regarding the divergent constructs, significant correlations were obtained between the SE-HRI and the affinity seeking instrument. The ISEL was not correlated with the SE-HRI. 
Table 8. Correlations ( $r$ ) of SE-HRI with Convergent and Discriminant Constructs

\begin{tabular}{lccc}
\hline Convergent & \multicolumn{3}{c}{ Discriminant } \\
\hline CUSE & $.332^{* *}$ & ISEL & .043 \\
KUT & $.396^{* *}$ & ASI & $.302^{* *}$ \\
GSE & $.382^{* *}$ & Affinity-Seeking Comp. & $.227^{* *}$ \\
NARS & $-.343^{* *}$ & Strategic Performance & $.279^{* *}$ \\
\hline${ }^{*} p<.05$. & & &
\end{tabular}

We chose "need to belong" (affinity seeking) as the discriminant variable, because interacting with a robot might satisfy the need to belong on a very basic level, and fulfilling these needs might result in better evaluations of the robot (as discussed in the article). Self-efficacy beliefs and affinity seeking should be separate constructs, but our data suggests that people scoring higher in affinity seeking also express a higher self-efficacy belief in human-robot interaction. Examining the two scales carefully, this might originate from a general wording issue. The ASI items are quite active in their phrasing ("If I put my mind to it, I could get anyone to like me." "I am good at getting others to want to hang around with me.") and somewhat goal oriented (increased likability in others). These phrasings are a bit similar to the SE-HRI scale in terms of reaching goals and active phrasing ("I can make a robot do what I want.", "I can fulfill certain tasks with the help of a robot."). In that sense, retrospectively, the ASI was not a good choice to be used as a discriminant validity measure. In future studies, we would suggest to use the "need to belong scale" by Krämer et al. [70], which focuses less on behavioral strategies but rather on the individual perceived importance of relationships and the fear of losing those relationships.

Moreover, we wanted to make sure that we generated items that measure self-efficacy in HRI against levels of task demands that represent gradations of challenges to successful performance in HRI. Therefore, we asked participants to rate all 10 items as either easy or difficult to ensure that items cover some range in perceived task difficulty. Indeed, five tasks seem to be perceived as easy by the majority of participants ( $>60 \%$ easy; see Appendix A5, Table 4 ) while four tasks were perceived as easy by about half of the participants ( $<60 \%$ easy; see Appendix A5, Table 4 ), and one was perceived as difficult by the majority (If a robot is doing something wrong, I could find a way to change its behavior: $27 \%$ easy).

6.3.3 Face Validity. In addition to the construct validity checks, we checked for face validity, i.e. "the appropriateness, sensibility, or relevance of the test and its items as they appear to the persons answering the test ([71], p. 78). We administered a small-scale survey asking for face validity of the scale. Participants received the final 10-item version of the scale alongside with a lay language definition of self-efficacy in HRI: "Self-efficacy is the self-belief in our competence or chances of successfully accomplishing a task and producing a favorable outcome. Self-efficacy in humanrobot-interaction is the self-belief in our competence or chances of successfully accomplishing a task together with a robot or with the use of a robot and producing a favorable outcome." We then asked participants to carefully read the scale and assess whether, in their opinion, the scale measures self-efficacy in HRI on a 7-point Likert scale from "strongly disagree" to "strongly agree." Our 23 participants (13 female; aged $20-47, M=27.74, S D=6.8$ ) overall stated high face validity of the scale $(M=5.65 ; S D=1.07$; Range 2-7).

6.3.4 Exploration of Self-Efficacy Beliefs in the Sample. As a last step, we wanted to explore how strong or weak people's self-efficacy in HRI beliefs are and which factors influence these beliefs. 
Previous experience. We asked participants whether they already interacted with a real robot. Those who did reported higher self-efficacy beliefs $(M=60.58 ; S D=23.18 ; n=59)$ than those who $\operatorname{did} \operatorname{not}\left(M=49.88 ; S D=22.96 ; n=137 ; F(1,195)=8.902, p=.003, \eta^{2}=.044\right)$.

Age differences. It could be assumed that older participants might have had less contact with robots and, thereby, might also score lower on the SE-HRI. Indeed, those participants who already interacted with a robot were younger $(M=32.29 ; S D=12.14 ; n=59)$ than those who did not $\left(M=38.90 ; S D=14.27 ; n=137 ; F(1,195)=9.639, p=.002, \eta^{2}=.047\right)$, but there was no significant correlation between age and the SE-HRI. However, the sample acquired for the validation of the short scale is not necessarily representative. We had only 14 cases of older adults $(60+)$ in the sample. Moreover, these 14 work frequently as "click workers".

\section{GENERAL DISCUSSION}

The aim of this work was to create and validate a measure for users' self-efficacy expectations in HRI. We will briefly discuss the scale development process and future work in this regard. We then discuss how the new scale can be used in HRI studies.

\subsection{Scale Development Process}

In four survey studies and one experiment, we developed a one-factorial scale with good psychometric properties for a long (18-items) and a short (10-items) version in the German and English language. Our data suggests that the items used in the scale assess a spectrum of interaction or task difficulty in HRI. Overall, both versions of the scale showed good model fit and good construct validity. Regarding the divergent construct "affinity seeking," we found unexpected positive correlations (sometimes for the English subsample, sometimes for both subsamples). An inspection of the scale's wording revealed that items in the ASI and SE-HRI are similar in terms of being formulated actively and goal-oriented. For future analyses on divergent construct validity, researchers should better use other non-related constructs or a different scale to include "need to belong" (e.g., Krämer et al. [70]).

Regarding future work, we want to further test the applicability of the newly developed scale, especially in studies involving children and technologically unexperienced elderly users, because these user groups are special target groups for current developments in companion robotics. Applying the scale will show whether the revised instructions are easier to understand and follow for these user groups. Another goal for future work is to provide other language versions of the scale.

Moreover, it would be very informative to include assessments of participants' stereotypes of robots. Working on negative attitudes toward robots in cross-cultural studies, Nomura and colleagues [53] found that Japanese have humanoid robots in mind when giving statements about their negative attitudes. This is not necessarily the case for other cultures. While the general picture of a computer setup or a smart phone is an established one and the same for every participant, the general picture of the robot can vary greatly. Robots can take a broad range of different forms-from robotic arms in factories, over autonomous vacuuming devices, to humanoid and android robots. Each of these forms imply different interaction and communication abilities [57] and, therefore, put different demands on the user on how to handle the system. This can greatly influence participants' efficacy beliefs regarding successful human-robot interaction.

\subsection{Why a Specialized Scale for HRI?}

While self-efficacy in HRI was correlated with general self-efficacy and computer self-efficacy, participants reported higher self-efficacy beliefs on the two latter constructs than on HRI selfefficacy (data from Study 5): 
-SE-HRI: $M=53.1$ on a scale from 1 to 100 ;

-General self-efficacy: $M=2.9$ on a scale from 1 to 4 ;

-Computer use self-efficacy: $M=4.6$ on a scale from 1 to 6 .

This supports the domain-specificity of self-efficacy, also with regard to HRI-related self-efficacy beliefs. Using more generalized scales to assess self-efficacy in HRI might lead to wrong estimates about how capable people feel in interacting with robots. This could have a negative impact, for instance, when designing trainings, because teachers and tutors would possibly design for participants whom they believe to be more capable and self-confident in their capabilities than they really are.

\subsection{Are Self-Efficacy Beliefs in HRI Stable or Subject to Change?}

According to Bandura [7], self-efficacy beliefs (and, therefore, also self-efficacy in HRI) can be altered via four mechanisms:

(1) enactive mastery experiences are most effective since they serve as indicators of capability: success raises self-efficacy perceptions, and failure lowers them;

(2) observing other people's success or failure can serve as proxy to determine one's own self-efficacy, especially when we regard ourselves as similar to the model;

(3) besides experiencing oneself or observing other people experiencing success, one can also be encouraged or discouraged by social persuasion; and

(4) depending on the level of self-efficacy, physiological factors influence self-efficacy, as well: in stressful situations, people with high self-efficacy for the task at hand might regard physiological arousal as normal, while people low in self-efficacy might interpret this as a sign for inability, thereby, reciprocally, further decreasing self-efficacy

Hence, self-efficacy beliefs in HRI are not a stable construct but might change due to mastery experience via observing other users successfully interacting with robots, or by persuasive messages telling users that they are capable of successfully interacting with a robot. In sum, the two most fruitful ways to positively influence self-efficacy perceptions are enactive mastery and vicarious experiences. With vicarious experiences, we mean observing a relevant other (peer) successfully interacting with a real robot. We do not believe that exposure to science fiction increases self-efficacy beliefs. In contrast, we believe that science fiction is less important for self-efficacy beliefs. Based on movies, users will most likely have exaggerated expectations about what a robot is able to do. But they are less likely to have exaggerated (low or high) expectations about how capable they feel about interacting with them and fulfilling certain goals while doing so. Self-efficacy beliefs can be distinct from science fiction exposure but will not be distinct from direct experience with robots. Interacting with robots and thereby gaining mastery experience will positively influence self-efficacy beliefs as will observing relevant others interacting with a robot. This can also be found in our data. We asked participants whether they already interacted with a real robot. We saw that participants who already interacted with a real robot reported higher self-efficacy beliefs than those who did not (in Study 5).

\subsection{Self-Efficacy in HRI as Predictor for Performance and Evaluations}

Following Bandura's work [5-7] we conceptualize self-efficacy in HRI as a strong predictor for performance, interaction satisfaction, and evaluation in human-robot-interactions. Bandura [5] hypothesized that self-efficacy beliefs mediate the effect of other determinants of performance on subsequent performance. Mediational analyses in different domains indeed lend support for a 
"dual causal linkage: Postulated determinants alter self-percepts of efficacy: and self-percepts of efficacy, in turn, affect motivation and action." (p. 360). A lot of work has proven this mediating or moderating role for different domains, for instance, regarding mathematical problem solving [55], job performance [61] or academic performance [54], and pain coping [4] or coping with stressful life events $[50,61]$, just to name a few areas of functioning. The same dual linkage as described above can be assumed for the domain of HRI.

Indeed, we found in our experimental study with the student sample that self-percepts of efficacy in HRI can be altered by interacting with a robot and thereby experiencing mastery of this new situation. We also assumed that an interaction situation in which participants have more opportunities to exert control over the robot, for instance, by teaching it relevant information, would lead to greater increases of self-efficacy than a more basic interaction. This was, however, not the case in our study. There was a general positive effect of interaction, but the "quality" of the interaction did not influence changes in self-efficacy beliefs.

Moreover, Bandura argued that constructs used to evaluate outcomes can be the result of selfefficacy judgments. We also found that the individual increase in self-efficacy perceptions predicted positive evaluations of the robot and the interaction at least within the study with the student sample. Given this, self-efficacy beliefs can be used in two ways in HRI studies.

7.4.1 SE-HRI as Moderator. First, self-efficacy can be used as a moderator. Just like personality trait variables and/or age and/or gender, researchers can include self-efficacy beliefs as an independent (IV) or moderating variable (MV). For this purpose, the scale should be administered at the beginning of the study before interaction with a robot or exposure to HRI material (like videos) takes place. Researchers can than use SE-HRI as a predictor for evaluation outcomes in, for instance, regression analyses (SE-HRI as IV). One could also split the sample into people scoring high or low in self-efficacy and run t-tests or Anovas with SE-HRI as IV. Moreover, SE-HRI scores can be used in analyses of covariance in order to control for the effect of self-efficacy beliefs that are not of primary interest in the experimental study (but will most likely have an influence on performance and evaluations).

7.4.2 SE-HRI as Mediator. Second, self-efficacy can be used as a mediator just as we used the concept as a mediator in Study 4 in order to explain evaluations of the robot. For this purpose, participants should fill in the questionnaire (at least) twice: prior and after an interaction with a robot or exposure to HRI material (like videos). Then researchers can calculate the individual change in self-efficacy in HRI beliefs by taking the SE-HRI scores after the interaction and subtracting the score from prior to interaction (i.e., calculate SE-HRI differences or deltas between the two measuring points). This new measure can than be used for mediation analyses in order to see whether the indirect effect of the independent variable on the outcome variable is mediated by self-efficacy changes.

\section{CONCLUSION}

We introduced the SE-HRI Scale, which was validated with a German and an English sample. We can shed light into the status quo of self-efficacy perceptions regarding HRI in our society, which will inform researchers as well as developers. Moreover, it can serve as an assessment for the efficiency of trainings, for instance, in the context of product launches. As a first proof of concept, we successfully applied the new measure in an experimental study. Based on the feedback from this study we created and tested a shorter version to put in use especially with senior samples or for time efficiency reasons. 


\section{A APPENDIX}

\section{A.1 Table 1: 18-Item Self-Efficacy in HRI Scale}

\begin{tabular}{|c|c|c|}
\hline No. & German Item & English Item \\
\hline \multirow[t]{2}{*}{1} & Ich könnte einen Roboter auf meine & I could set up a robot according to \\
\hline & Wünsche und meine Umgebung einrichten. & my wishes and my environment. \\
\hline 2 & $\begin{array}{l}\text { Ich könnte einen Roboter dazu bringen, } \\
\text { eine bestimmte Aufgabe zu erfüllen. }\end{array}$ & $\begin{array}{l}\text { I could get a robot to perform a } \\
\text { specific task. }\end{array}$ \\
\hline 3 & $\begin{array}{l}\text { Ich kenne mich gut mit Technik aus, daher } \\
\text { könnte ich auch sicherlich einen Roboter } \\
\text { verwenden. }\end{array}$ & $\begin{array}{l}\text { I am familiar with technology; } \\
\text { therefore, I think I could use a robot }\end{array}$ \\
\hline 4 & $\begin{array}{l}\text { Ich denke, ich kann einen Roboter so } \\
\text { einstellen, dass er mich im Alltag } \\
\text { unterstützen kann. }\end{array}$ & $\begin{array}{l}\text { I think I could adjust a robot the way } \\
\text { that it could help me in my daily life }\end{array}$ \\
\hline 5 & Es ist einfach, einen Roboter zu benutzen. & It is easy to use a robot. \\
\hline 6 & Wenn ich eine Aufgabe mit Hilfe eines & If I should solve a problem with the \\
\hline & $\begin{array}{l}\text { Roboters lösen sollte, dann würde mir dies } \\
\text { gelingen. }\end{array}$ & ot, I could do that \\
\hline 7 & $\begin{array}{l}\text { Es wäre kein Problem für mich, mit Hilfe } \\
\text { eines Roboters ein bestimmtes Ziel zu } \\
\text { erreichen. }\end{array}$ & $\begin{array}{l}\text { To achieve a specific goal with the } \\
\text { assistance of a robot will not be a } \\
\text { problem for me. }\end{array}$ \\
\hline 8 & $\begin{array}{l}\text { Wenn ich mich bemühe, könnte ich einem } \\
\text { Roboter etwas beibringen. }\end{array}$ & $\begin{array}{l}\text { I could teach a robot something if I } \\
\text { would try hard enough. }\end{array}$ \\
\hline 9 & $\begin{array}{l}\text { Ich könnte leicht lernen, wie man einen } \\
\text { Roboter benutzt. }\end{array}$ & $\begin{array}{l}\text { I could easily learn how to use a } \\
\text { robot. }\end{array}$ \\
\hline 10 & $\begin{array}{l}\text { Ich könnte einem Roboter einfache } \\
\text { Aufgaben beibringen. }\end{array}$ & $\begin{array}{l}\text { I could teach a robot to complete } \\
\text { easy tasks. }\end{array}$ \\
\hline 11 & $\begin{array}{l}\text { Wenn ich einen Roboter verwenden würde, } \\
\text { wüsste ich immer, wie und warum er etwas } \\
\text { macht. }\end{array}$ & $\begin{array}{l}\text { If I would use a robot, I would } \\
\text { always know how and why it } \\
\text { behaves like it does. }\end{array}$ \\
\hline 12 & $\begin{array}{l}\text { Ich könnte einfache Einstellungen an einem } \\
\text { Roboter selbst vornehmen. }\end{array}$ & $\begin{array}{l}\text { I could do easy adjustments on a } \\
\text { robot by myself. }\end{array}$ \\
\hline 13 & $\begin{array}{l}\text { Ich könnte einen Roboter im Alltag } \\
\text { benutzen. }\end{array}$ & I could use a robot in daily life. \\
\hline 14 & $\begin{array}{l}\text { Mit einem Roboter zu interagieren, würde } \\
\text { mir keine Probleme bereiten. }\end{array}$ & $\begin{array}{l}\text { I would feel comfortable while } \\
\text { interacting with the robot. }\end{array}$ \\
\hline 15 & $\begin{array}{l}\text { Wenn ein Roboter etwas nicht richtig } \\
\text { macht, finde ich Mittel und Wege dies zu } \\
\text { ändern. }\end{array}$ & $\begin{array}{l}\text { If a robot is doing something wrong, } \\
\text { I could find a way to change its } \\
\text { behavior. }\end{array}$ \\
\hline 16 & Roboter sind einfach zu kontrollieren. & Robots are easy to control. \\
\hline 17 & $\begin{array}{l}\text { Ich könnte einen Roboter so einsetzen, dass } \\
\text { ich dadurch Zeit sparen würde. }\end{array}$ & $\begin{array}{l}\text { I could deploy a robot in a specific } \\
\text { way to save time. }\end{array}$ \\
\hline 18 & $\begin{array}{l}\text { Ich bin mir sicher, dass ich einen Roboter } \\
\text { steuern könnte. }\end{array}$ & $\begin{array}{l}\text { I am very confident in my abilities to } \\
\text { control a robot. }\end{array}$ \\
\hline
\end{tabular}

Tested with a 6-point Likert scale from 1 ("Strongly Disagree”) to 6 ("Strongly Agree"). 


\section{A.2 Table 2: List of the Initial 50 Items of the Self-Efficacy in HRI Scale}

\begin{tabular}{|c|c|c|c|c|c|c|}
\hline & Items (English) & Items (German) & Source & Original (English) & Original (German) & Exclusion \\
\hline SE-HRI01 & $\begin{array}{l}\text { I think working } \\
\text { with a robot is } \\
\text { very easy. }\end{array}$ & $\begin{array}{l}\text { Ich stelle mir das } \\
\text { Arbeiten mit Robotern } \\
\text { sehr einfach vor. }\end{array}$ & $\begin{array}{l}\text { Computer User } \\
\text { Self-Efficacy } \\
\text { (CUSE) }\end{array}$ & $\begin{array}{l}\text { I find working with } \\
\text { computers very } \\
\text { easy. }\end{array}$ & $\begin{array}{l}\text { Ich finde das Arbeiten } \\
\text { mit Computern sehr } \\
\text { einfach. }\end{array}$ & CFA \\
\hline SE-HRI01 & $\begin{array}{l}\text { I think working } \\
\text { with a robot is } \\
\text { very easy. }\end{array}$ & $\begin{array}{l}\text { Ich stelle mir das } \\
\text { Arbeiten mit Robotern } \\
\text { sehr einfach vor. }\end{array}$ & $\begin{array}{l}\text { Computer User } \\
\text { Self-Efficacy } \\
\text { (CUSE) }\end{array}$ & $\begin{array}{l}\text { I find working with } \\
\text { computers very } \\
\text { easy. }\end{array}$ & $\begin{array}{l}\text { Ich finde das Arbeiten } \\
\text { mit Computern sehr } \\
\text { einfach. }\end{array}$ & CFA \\
\hline SE-HRI02 & $\begin{array}{l}\text { I am very unsure } \\
\text { of my abilities to } \\
\text { use a robot. }\end{array}$ & $\begin{array}{l}\text { Ich bin sehr unsicher } \\
\text { über meine Fähigkeiten } \\
\text { im Umgang mit einem } \\
\text { Roboter. }\end{array}$ & CUSE & $\begin{array}{l}\text { I am very unsure of } \\
\text { my abilities to use } \\
\text { computers. }\end{array}$ & $\begin{array}{l}\text { Ich bin sehr unsicher } \\
\text { über meine Fähigkeiten } \\
\text { im Umgang mit } \\
\text { Computern. }\end{array}$ & CFA \\
\hline SE-HRI03 & $\begin{array}{l}\text { Robots frighten } \\
\text { me. }\end{array}$ & $\begin{array}{l}\text { Roboter machen mir } \\
\text { Angst. }\end{array}$ & CUSE & $\begin{array}{l}\text { Computers frighten } \\
\text { me. }\end{array}$ & $\begin{array}{l}\text { Computer machen mir } \\
\text { Angst. }\end{array}$ & EFA \\
\hline SE-HRI04 & $\begin{array}{l}\text { I could enjoy } \\
\text { working with } \\
\text { robots. }\end{array}$ & $\begin{array}{l}\text { Ich könnte beim Umgang } \\
\text { mit Robotern Spaß haben. }\end{array}$ & CUSE & $\begin{array}{l}\text { I enjoy working } \\
\text { with computers. }\end{array}$ & $\begin{array}{l}\text { Beim Arbeiten mit } \\
\text { Computern habe ich } \\
\text { Spaß. }\end{array}$ & EFA \\
\hline SE-HRI05 & $\begin{array}{l}\text { I am very } \\
\text { confident in my } \\
\text { abilities to } \\
\text { control a robot. }\end{array}$ & $\begin{array}{l}\text { Ich bin mir sicher, dass } \\
\text { ich einen Roboter steuern } \\
\text { könnte. }\end{array}$ & CUSE & $\begin{array}{l}\text { I am very confident } \\
\text { in my abilities to } \\
\text { make use of } \\
\text { computers. }\end{array}$ & $\begin{array}{l}\text { Ich bin sehr sicher in } \\
\text { meinen Fähigkeiten, } \\
\text { Computer zu nutzen. }\end{array}$ & Final \\
\hline SE-HRI06 & $\begin{array}{l}\text { I find it difficult } \\
\text { to get a robot to } \\
\text { do what I want } \\
\text { it to. }\end{array}$ & $\begin{array}{l}\text { Ich denke, es ist } \\
\text { schwierig, einen Roboter } \\
\text { dazu zu bringen, das zu } \\
\text { tun, was ich von ihm } \\
\text { möchte. }\end{array}$ & CUSE & $\begin{array}{l}\text { I find it difficult to } \\
\text { get computers to do } \\
\text { what I want them } \\
\text { to. }\end{array}$ & $\begin{array}{l}\text { Ich finde es schwierig, } \\
\text { Computer dazu zu } \\
\text { bringen, das zu tun, was } \\
\text { ich von ihnen will. }\end{array}$ & EFA \\
\hline SE-HRI07 & $\begin{array}{l}\text { Usually, I easily } \\
\text { learn how to use } \\
\text { new } \\
\text { technologies or } \\
\text { devices. }\end{array}$ & $\begin{array}{l}\text { Die Bedienung neuer } \\
\text { Technologien und Geräte } \\
\text { lerne ich meist schnell. }\end{array}$ & CUSE & $\begin{array}{l}\text { I usually find it easy } \\
\text { to learn how to use } \\
\text { a new software } \\
\text { package. }\end{array}$ & $\begin{array}{l}\text { Ich finde es } \\
\text { normalerweise einfach } \\
\text { zu lernen, wie man ein } \\
\text { neues } \\
\text { Computerprogramm } \\
\text { verwendet. }\end{array}$ & EFA \\
\hline SE-HRI08 & $\begin{array}{l}\text { I would waste a } \\
\text { lot of time while } \\
\text { learning how to } \\
\text { use a robot. }\end{array}$ & $\begin{array}{l}\text { Wenn ich einen Roboter } \\
\text { hätte, bräuchte ich viel } \\
\text { Zeit, um den Umgang mit } \\
\text { ihm zu erlernen. }\end{array}$ & CUSE & $\begin{array}{l}\text { I seem to waste a lot } \\
\text { of time struggling } \\
\text { with computers. }\end{array}$ & $\begin{array}{l}\text { Vermutlich } \\
\text { verschwende ich eine } \\
\text { Menge Zeit, wenn ich } \\
\text { mich mit Computern } \\
\text { abmühe. }\end{array}$ & EFA \\
\hline SE-HRI09 & Robots baffle me. & Roboter verwirren mich. & CUSE & $\begin{array}{l}\text { Computer jargon } \\
\text { baffles me. }\end{array}$ & $\begin{array}{l}\text { Computerbegriffe } \\
\text { verwirren mich. }\end{array}$ & EFA \\
\hline SE-HRI10 & $\begin{array}{l}\text { Robots are far } \\
\text { too complicated } \\
\text { for me. }\end{array}$ & $\begin{array}{l}\text { Roboter sind viel zu } \\
\text { kompliziert für mich. }\end{array}$ & CUSE & $\begin{array}{l}\text { Computers are far } \\
\text { too complicated for } \\
\text { me. }\end{array}$ & $\begin{array}{l}\text { Computer sind viel zu } \\
\text { kompliziert für mich. }\end{array}$ & EFA \\
\hline SE-HRI11 & $\begin{array}{l}\text { I think I could } \\
\text { adjust a robot } \\
\text { the way, that it } \\
\text { could help me in } \\
\text { my daily life. }\end{array}$ & $\begin{array}{l}\text { Ich denke, ich kann einen } \\
\text { Roboter so einstellen, } \\
\text { dass er mich im Alltag } \\
\text { unterstützen kann. }\end{array}$ & CUSE & $\begin{array}{l}\text { Computers are good } \\
\text { aids to learning }\end{array}$ & $\begin{array}{l}\text { Computer sind gute } \\
\text { Hilfsmittel beim Lernen. }\end{array}$ & Final \\
\hline SE-HRI12 & $\begin{array}{l}\text { If I would use a } \\
\text { robot, I would } \\
\text { always know, } \\
\text { how and why it } \\
\text { behaves like it } \\
\text { does. }\end{array}$ & $\begin{array}{l}\text { Wenn ich einen Roboter } \\
\text { verwenden würde, } \\
\text { wüsste ich immer, wie } \\
\text { und warum er etwas } \\
\text { macht. }\end{array}$ & CUSE & $\begin{array}{l}\text { Sometimes, when } \\
\text { using a computer, } \\
\text { things seem to } \\
\text { happen and I don't } \\
\text { know why. }\end{array}$ & $\begin{array}{l}\text { Wenn ich einen } \\
\text { Computer verwende, } \\
\text { dann scheinen } \\
\text { manchmal Dinge } \\
\text { einfach so zu passieren, } \\
\text { und ich weiß nicht } \\
\text { warum. }\end{array}$ & Final \\
\hline
\end{tabular}

(Continued) 


\begin{tabular}{|c|c|c|c|c|c|c|}
\hline & Items (English) & Items (German) & Source & Original (English) & Original (German) & Exclusion \\
\hline SE-HRI13 & $\begin{array}{l}\text { Dealing with } \\
\text { robots would be } \\
\text { very hard for } \\
\text { me. }\end{array}$ & $\begin{array}{l}\text { Der Umgang mit einem } \\
\text { Roboter würde mir sehr } \\
\text { schwer fallen. }\end{array}$ & CUSE & $\begin{array}{l}\text { As far as computers } \\
\text { go, I don't consider } \\
\text { myself to be very } \\
\text { competent. }\end{array}$ & $\begin{array}{l}\text { Was Computer } \\
\text { anbelangt, halte ich } \\
\text { mich selbst für nicht } \\
\text { sehr kompetent. }\end{array}$ & EFA \\
\hline SE-HRI14 & $\begin{array}{l}\text { I could deploy a } \\
\text { robot in a } \\
\text { specific way to } \\
\text { save time. }\end{array}$ & $\begin{array}{l}\text { Ich könnte einen Roboter } \\
\text { so einsetzen, dass ich } \\
\text { dadurch Zeit sparen } \\
\text { würde. }\end{array}$ & CUSE & $\begin{array}{l}\text { Computers help me } \\
\text { to save a lot of time. }\end{array}$ & $\begin{array}{l}\text { Computer helfen mir, } \\
\text { eine Menge Zeit zu } \\
\text { sparen. }\end{array}$ & Final \\
\hline SE-HRI15 & $\begin{array}{l}\text { If I should teach } \\
\text { a robot } \\
\text { something I, } \\
\text { would worry } \\
\text { about to } \\
\text { do/doing } \\
\text { something } \\
\text { wrong. }\end{array}$ & $\begin{array}{l}\text { Wenn ich einem Roboter } \\
\text { etwas beibringen sollte, } \\
\text { hätte ich Angst, etwas } \\
\text { falsch zu machen. }\end{array}$ & CUSE & $\begin{array}{l}\text { When using } \\
\text { computers I worry } \\
\text { that I might press } \\
\text { the wrong button } \\
\text { and damage it. }\end{array}$ & $\begin{array}{l}\text { Wenn ich einen } \\
\text { Computer benutze, } \\
\text { dann befürchte ich, dass } \\
\text { ich eine falsche Taste } \\
\text { drücken und ihn } \\
\text { beschädigen könnte. }\end{array}$ & CFA \\
\hline SE-HRI16 & $\begin{array}{l}\text { I think } \\
\text { programming } \\
\text { robots is really } \\
\text { hard. }\end{array}$ & $\begin{array}{l}\text { Ich denke, es ist schwer, } \\
\text { einen Roboter zu } \\
\text { programmieren. }\end{array}$ & self-generated & & & EFA \\
\hline SE-HRI17 & $\begin{array}{l}\text { Robots fascinate } \\
\text { me. }\end{array}$ & Roboter faszinieren mich. & $\begin{array}{l}\text { Technique } \\
\text { related } \\
\text { Self-Concept } \\
\text { (TSK) }\end{array}$ & $\begin{array}{l}\text { Technology } \\
\text { fascinates me. }\end{array}$ & Technik fasziniert mich. & EFA \\
\hline SE-HRI18 & $\begin{array}{l}\text { I could } \\
\text { understand how } \\
\text { a robot works. }\end{array}$ & $\begin{array}{l}\text { Ich könnte verstehen, wie } \\
\text { Roboter funktionieren. }\end{array}$ & TSK & $\begin{array}{l}\text { I want to } \\
\text { understand how } \\
\text { technical devices } \\
\text { work. }\end{array}$ & $\begin{array}{l}\text { Ich will verstehen, wie } \\
\text { technische Geräte } \\
\text { funktionieren. }\end{array}$ & CFA \\
\hline SE-HRI19 & $\begin{array}{l}\text { If a robot is } \\
\text { doing something } \\
\text { wrong, I could } \\
\text { find a way to } \\
\text { change its } \\
\text { behavior. }\end{array}$ & $\begin{array}{l}\text { Wenn ein Roboter etwas } \\
\text { nicht richtig macht, finde } \\
\text { ich Mittel und Wege dies } \\
\text { zu ändern. }\end{array}$ & TSK & $\begin{array}{l}\text { When I am } \\
\text { confronted with } \\
\text { technical problems, } \\
\text { I could find a ways } \\
\text { to solve them. }\end{array}$ & $\begin{array}{l}\text { Wenn ich mit } \\
\text { technischen Problemen } \\
\text { konfrontiert bin, finde } \\
\text { ich Mittel und Wege, sie } \\
\text { zu lösen. }\end{array}$ & final \\
\hline SE-HRI20 & $\begin{array}{l}\text { The } \\
\text { functionality of } \\
\text { robots often } \\
\text { seems arbitrary } \\
\text { to me. }\end{array}$ & $\begin{array}{l}\text { Die Funktionsweise von } \\
\text { Robotern erscheint mir } \\
\text { oft willkürlich. }\end{array}$ & TSK & $\begin{array}{l}\text { The functionality of } \\
\text { technology often } \\
\text { seems arbitrary to } \\
\text { me }\end{array}$ & $\begin{array}{l}\text { Die Funktionsweise von } \\
\text { Technik erscheint mir } \\
\text { oft willkürlich. }\end{array}$ & EFA \\
\hline SE-HRI21 & $\begin{array}{l}\text { I could adjust a } \\
\text { robot according } \\
\text { to my individual } \\
\text { preferences. }\end{array}$ & $\begin{array}{l}\text { Ich könnte einen Roboter } \\
\text { individuell für mich } \\
\text { einstellen. }\end{array}$ & self-generated & & & CFA \\
\hline SE-HRI22 & $\begin{array}{l}\text { I could teach a } \\
\text { robot something, } \\
\text { if I would try } \\
\text { hard enough. }\end{array}$ & $\begin{array}{l}\text { Wenn ich mich bemühe, } \\
\text { könnte ich einem Roboter } \\
\text { etwas beibringen. }\end{array}$ & $\begin{array}{l}\text { General } \\
\text { Self-Efficacy } \\
\text { (GSE) }\end{array}$ & $\begin{array}{l}\text { I can always } \\
\text { manage to solve } \\
\text { difficult problems if } \\
\text { I try hard enough. }\end{array}$ & $\begin{array}{l}\text { Die Lösung schwieriger } \\
\text { Probleme gelingt mir } \\
\text { immer, wenn ich mich } \\
\text { darum bemühe. }\end{array}$ & final \\
\hline SE-HRI23 & $\begin{array}{l}\text { To achieve a } \\
\text { specific goal } \\
\text { with the } \\
\text { assistance of a } \\
\text { robot, will not } \\
\text { be a problem for } \\
\text { me. }\end{array}$ & $\begin{array}{l}\text { Es wäre kein Problem für } \\
\text { mich, mit Hilfe eines } \\
\text { Roboters ein bestimmtes } \\
\text { Ziel zu erreichen. }\end{array}$ & GSE & $\begin{array}{l}\text { It is easy for me to } \\
\text { stick to my aims } \\
\text { and accomplish my } \\
\text { goals. }\end{array}$ & $\begin{array}{l}\text { Es bereitet mir keine } \\
\text { Schwierigkeiten, meine } \\
\text { Absichten und Ziele zu } \\
\text { verwirklichen. }\end{array}$ & final \\
\hline
\end{tabular}




\begin{tabular}{|c|c|c|c|c|c|c|}
\hline & Items (English) & Items (German) & Source & Original (English) & Original (German) & Exclusion \\
\hline SE-HRI24 & $\begin{array}{l}\text { If I should solve } \\
\text { a problem with } \\
\text { the assistance of } \\
\text { a robot, I could } \\
\text { do that. }\end{array}$ & $\begin{array}{l}\text { Wenn ich eine Aufgabe } \\
\text { mit Hilfe eines Roboters } \\
\text { lösen sollte, dann würde } \\
\text { mir dies gelingen. }\end{array}$ & GSE & $\begin{array}{l}\text { If I am in trouble, I } \\
\text { can usually think of } \\
\text { a solution. }\end{array}$ & $\begin{array}{l}\text { Wenn eine neue Sache } \\
\text { auf mich zukommt, } \\
\text { weiß ich, wie ich damit } \\
\text { umgehen kann. }\end{array}$ & final \\
\hline SE-HRI25 & $\begin{array}{l}\text { I would feel } \\
\text { comfortable } \\
\text { while } \\
\text { interacting with } \\
\text { the robot. }\end{array}$ & $\begin{array}{l}\text { Mit einem Roboter zu } \\
\text { interagieren, würde mir } \\
\text { keine Probleme bereiten. }\end{array}$ & self-generated & & & final \\
\hline SE-HRI26 & $\begin{array}{l}\text { I could work } \\
\text { with a robot } \\
\text { without any } \\
\text { assistance. }\end{array}$ & $\begin{array}{l}\text { Ich könnte ohne Hilfe mit } \\
\text { einem Roboter arbeiten. }\end{array}$ & $\begin{array}{l}\text { Unified theory } \\
\text { of acceptance } \\
\text { and use of } \\
\text { technology - } \\
\text { Questionnaire }\end{array}$ & $\begin{array}{l}\text { I could complete a } \\
\text { job or task using the } \\
\text { system, if there was } \\
\text { no one around to } \\
\text { tell me what to do. }\end{array}$ & $\begin{array}{l}\text { Ich könnte eine Aufgabe } \\
\text { mithilfe des Systems } \\
\text { bearbeiten, auch wenn } \\
\text { mir niemand erklären } \\
\text { könnte wie das } \\
\text { funktioniert. }\end{array}$ & CFA \\
\hline SE-HRI27 & $\begin{array}{l}\text { I could program } \\
\text { a robot. }\end{array}$ & $\begin{array}{l}\text { Ich könnte einen Roboter } \\
\text { programmieren. }\end{array}$ & self-generated & & & CFA \\
\hline SE-HRI28 & $\begin{array}{l}\text { I could work } \\
\text { with a robot, if I } \\
\text { had a good } \\
\text { manual. }\end{array}$ & $\begin{array}{l}\text { Ich könnte mit einem } \\
\text { Roboter arbeiten, wenn } \\
\text { ich eine gute Anleitung } \\
\text { hätte. }\end{array}$ & self-generated & & & EFA \\
\hline SE-HRI29 & $\begin{array}{l}\text { When dealing } \\
\text { with robots, I } \\
\text { could exhaust } \\
\text { the full } \\
\text { potential. }\end{array}$ & $\begin{array}{l}\text { Im Umgang mit einem } \\
\text { Roboter könnte ich das } \\
\text { mögliche Potenzial voll } \\
\text { ausschöpfen. }\end{array}$ & $\begin{array}{l}\text { Multi- } \\
\text { dimensional } \\
\text { Robot Attitude } \\
\text { Scale (MDRA) }\end{array}$ & $\begin{array}{l}\text { I can make full use } \\
\text { of a robot. }\end{array}$ & $\begin{array}{l}\text { Im Umgang mit einem } \\
\text { Roboter könnte ich das } \\
\text { mögliche Potenzial voll } \\
\text { ausschöpfen. }\end{array}$ & CFA \\
\hline SE-HRI30 & $\begin{array}{l}\text { It is easy to use a } \\
\text { robot. }\end{array}$ & $\begin{array}{l}\text { Es ist einfach, einen } \\
\text { Roboter zu benutzen. }\end{array}$ & MDRA & $\begin{array}{l}\text { It is easy to use a } \\
\text { robot. }\end{array}$ & $\begin{array}{l}\text { Es ist einfach, einen } \\
\text { Roboter zu benutzen. }\end{array}$ & final \\
\hline SE-HRI31 & $\begin{array}{l}\text { I can easily learn } \\
\text { how to use a } \\
\text { robot }\end{array}$ & $\begin{array}{l}\text { Ich könnte leicht lernen, } \\
\text { wie man einen Roboter } \\
\text { benutzt. }\end{array}$ & MDRA & $\begin{array}{l}\text { I can easily learn } \\
\text { how to use a robot }\end{array}$ & $\begin{array}{l}\text { Ich könnte leicht lernen, } \\
\text { wie man einen Roboter } \\
\text { benutzt. }\end{array}$ & final \\
\hline SE-HRI32 & $\begin{array}{l}\text { I could get a } \\
\text { robot to perform } \\
\text { a specific task. }\end{array}$ & $\begin{array}{l}\text { Ich könnte einen Roboter } \\
\text { dazu bringen, eine } \\
\text { bestimmte Aufgabe zu } \\
\text { erfüllen. }\end{array}$ & self-generated & & & final \\
\hline SE-HRI33 & $\begin{array}{l}\text { Robots are } \\
\text { science fiction } \\
\text { for me. }\end{array}$ & $\begin{array}{l}\text { Roboter sind für mich } \\
\text { Science-Fiction. }\end{array}$ & self-generated & & & EFA \\
\hline SE-HRI34 & $\begin{array}{l}\text { To me, robots } \\
\text { are a book of } \\
\text { seven seals. }\end{array}$ & $\begin{array}{l}\text { Roboter sind für mich ein } \\
\text { Buch mit sieben Siegeln. }\end{array}$ & self-generated & & & EFA \\
\hline SE-HRI35 & $\begin{array}{l}\text { I think it would } \\
\text { be difficult, to } \\
\text { teach a robot } \\
\text { something. }\end{array}$ & $\begin{array}{l}\text { Ich denke, es ist schwer, } \\
\text { einem Roboter etwas } \\
\text { beizubringen. }\end{array}$ & self-generated & & & EFA \\
\hline SE-HRI36 & $\begin{array}{l}\text { I do not have } \\
\text { any influence on } \\
\text { what a robot is } \\
\text { doing. }\end{array}$ & $\begin{array}{l}\text { Ich habe keinen Einfluss } \\
\text { darauf, was ein Roboter } \\
\text { macht. }\end{array}$ & self-generated & & & final \\
\hline SE-HRI37 & $\begin{array}{l}\text { I think it would } \\
\text { be difficult, to } \\
\text { get a robot to } \\
\text { behave in a } \\
\text { specific way. }\end{array}$ & $\begin{array}{l}\text { Ich denke, es ist schwer, } \\
\text { einen Roboter dazu zu } \\
\text { bringen, ein bestimmtes } \\
\text { Verhalten zu zeigen. }\end{array}$ & self-generated & & & EFA \\
\hline
\end{tabular}




\begin{tabular}{|c|c|c|c|c|c|c|}
\hline & Items (English) & Items (German) & Source & Original (English) & Original (German) & Exclusion \\
\hline SE-HRI38 & $\begin{array}{l}\text { I could use a } \\
\text { robot in daily } \\
\text { life. }\end{array}$ & $\begin{array}{l}\text { Ich könnte einen Roboter } \\
\text { im Alltag benutzen. }\end{array}$ & self-generated & & & final \\
\hline SE-HRI39 & $\begin{array}{l}\text { A robot does } \\
\text { what it wants. }\end{array}$ & $\begin{array}{l}\text { Ein Roboter macht, was } \\
\text { er will. }\end{array}$ & self-generated & & & CFA \\
\hline SE-HRI40 & $\begin{array}{l}\text { I do not have } \\
\text { any influence on } \\
\text { how a robot } \\
\text { behaves. }\end{array}$ & $\begin{array}{l}\text { Ich habe keinen Einfluss } \\
\text { darauf, wie ein Roboter } \\
\text { sich verhält. }\end{array}$ & self-generated & & & final \\
\hline SE-HRI41 & $\begin{array}{l}\text { I could teach a } \\
\text { robot to } \\
\text { complete easy } \\
\text { tasks. }\end{array}$ & $\begin{array}{l}\text { Ich könnte einem } \\
\text { Roboter einfache } \\
\text { Aufgaben beibringen. }\end{array}$ & self-generated & & & final \\
\hline SE-HRI42 & $\begin{array}{l}\text { I usually try out } \\
\text { new technical } \\
\text { devices, before } \\
\text { taking a look at } \\
\text { the manual. }\end{array}$ & $\begin{array}{l}\text { Ich probiere technische } \\
\text { Geräte erst aus, bevor ich } \\
\text { mir die Anleitung ansehe. }\end{array}$ & self-generated & & & EFA \\
\hline SE-HRI43 & $\begin{array}{l}\text { I am familiar } \\
\text { with technology, } \\
\text { therefor I think I } \\
\text { could use a } \\
\text { robot. }\end{array}$ & $\begin{array}{l}\text { Ich kenne mich gut mit } \\
\text { Technik aus, daher } \\
\text { könnte ich auch } \\
\text { sicherlich einen Roboter } \\
\text { verwenden. }\end{array}$ & self-generated & & & final \\
\hline SE-HRI44 & $\begin{array}{l}\text { I could program } \\
\text { a robot } \\
\text { according to my } \\
\text { personal needs. }\end{array}$ & $\begin{array}{l}\text { Ich könnte einen Roboter } \\
\text { nach meinen } \\
\text { Bedürfnissen } \\
\text { programmieren. }\end{array}$ & self-generated & & & CFA \\
\hline SE-HRI45 & $\begin{array}{l}\text { Robots are easy } \\
\text { to control. }\end{array}$ & $\begin{array}{l}\text { Roboter sind einfach zu } \\
\text { kontrollieren. }\end{array}$ & self-generated & & & final \\
\hline SE-HRI46 & $\begin{array}{l}\text { I could set up a } \\
\text { robot according } \\
\text { to my wishes } \\
\text { and my } \\
\text { environment. }\end{array}$ & $\begin{array}{l}\text { Ich könnte einen Roboter } \\
\text { auf meine Wünsche und } \\
\text { meine Umgebung } \\
\text { einrichten. }\end{array}$ & self-generated & & & \\
\hline SE-HRI47 & $\begin{array}{l}\text { I do not have } \\
\text { any control over } \\
\text { what a robot is } \\
\text { doing. }\end{array}$ & $\begin{array}{l}\text { Ich habe keine Kontrolle } \\
\text { darüber, was ein Roboter } \\
\text { macht. }\end{array}$ & self-generated & & & final \\
\hline SE-HRI48 & $\begin{array}{l}\text { I could do easy } \\
\text { adjustments on a } \\
\text { robot by myself. }\end{array}$ & $\begin{array}{l}\text { Ich könnte einfache } \\
\text { Einstellungen an einem } \\
\text { Roboter selbst } \\
\text { vornehmen. }\end{array}$ & self-generated & & & final \\
\hline SE-HRI49 & $\begin{array}{l}\text { If there is a } \\
\text { problem with a } \\
\text { robot, I would } \\
\text { try to solve it by } \\
\text { myself, before } \\
\text { asking } \\
\text { somebody for } \\
\text { help. }\end{array}$ & $\begin{array}{l}\text { Wenn ein Problem mit } \\
\text { einem Roboter auftritt, } \\
\text { würde ich erst versuchen } \\
\text { es selbst zu lösen, bevor } \\
\text { ich jemanden um Hilfe } \\
\text { bitte. }\end{array}$ & self-generated & & & CFA \\
\hline SE-HRI50 & $\begin{array}{l}\text { I could interact } \\
\text { with a robot in a } \\
\text { group. }\end{array}$ & $\begin{array}{l}\text { Ich könnte in einer } \\
\text { Gruppe mit einem } \\
\text { Roboter interagieren. }\end{array}$ & self-generated & & & CFA \\
\hline
\end{tabular}

Items displayed with the respective source of the item (if applicable) and a note whether the respective item has been excluded during EFA or CFA or is part of the final version of the scale. 


\section{A.3 Table 3: Excluded Items and Explanations from Study 2 and 5}

\begin{tabular}{lcc}
\hline & Excluded item & Reason \\
\hline Study 2 & I am very unsure of my abilities to use a & high residual loading $\left(\sigma^{2} r=.804\right)$, formulated to
\end{tabular}

(step 1) robot. vaguely

If I should teach a robot something I, would high residual loading $\left(\sigma^{2} r=.805\right)$ due to reference

worry about to do/doing something wrong. to a the strong and unrelated construct of "fear" in the German version

A robot does what it wants. $\quad$ high residual loading $\left(\sigma^{2} r=.704\right)$, formulated to vaguely

I think programming robots is really hard. highly intercorrelated $(r(448)=.727, p<.001)$, reference to "programming" caused

misinterpretation in seniors

I could program a robot.

highly intercorrelated $(r(448)=.727, p<.001)$,

reference to "programming" caused

misinterpretation in seniors

I could interact with a robot in a group. ambiguity because the structure of the group is unclear

I could adjust a robot according to my individual preferences.

Study 2 When dealing with robots, I could exhaust

(step 2) the full potential.

I could work with a robot without any assistance.

redundant to item SE-HRI $46(r(448)=.854, p<.001)$

If there is a problem with a robot, I would try to solve it by myself, before asking somebody for help.

ambiguity because "full potential" depends on individual interpretation, reflects in item difficulty $(M=.38 ; S D=.31)^{*}$

includes references to a third person's competence that is not defined; high residual loading $\left(\sigma^{2} r=.518\right)$

includes references to a third person's competence that is not defined; high residual loading $\left(\sigma^{2} r=\right.$ .613); low item difficulty $(M=.60 ; S D=.31)$

I could understand how a robot works. high residual loading $\left(\sigma^{2} r=.587\right)$

I think working with a robot is very easy.

high residual loading $\left(\sigma^{2} r=.598\right)$

Study 5 I could easily learn how to use a robot. item discrimination $<.657$; factor loadings $<.674^{* *}$

If I would use a robot, I would always know, item discrimination $<.657$; factor loadings $<.674^{* *}$ how and why it behaves like it does.

Robots are easy to control. item discrimination $<.657$; factor loadings $<.674^{* *}$

I could deploy a robot in a specific way to item discrimination $<.657$; factor loadings $<.674^{* *}$ save time.

I am very confident in my abilities to $\quad$ item discrimination $<.657$; factor loadings $<.674^{* *}$ control a robot.

could set up a robot according to my wishes redundant to SE-HRI 32 (English sample: $r=.859$; and my environment.

German sample: $r=.845$ )

It is easy to use a robot.

If I should solve a problem with the

assistance of a robot, I could do that.

Item labels refer to Appendix A2, Table 2.

Note: *overall item difficulty $(M=.49 ; S D=.29)$.

${ }^{* *} 5$ weakest items from 18 -item version. 


\section{A.4 Figure 1: Scatter Plots from Study 3}
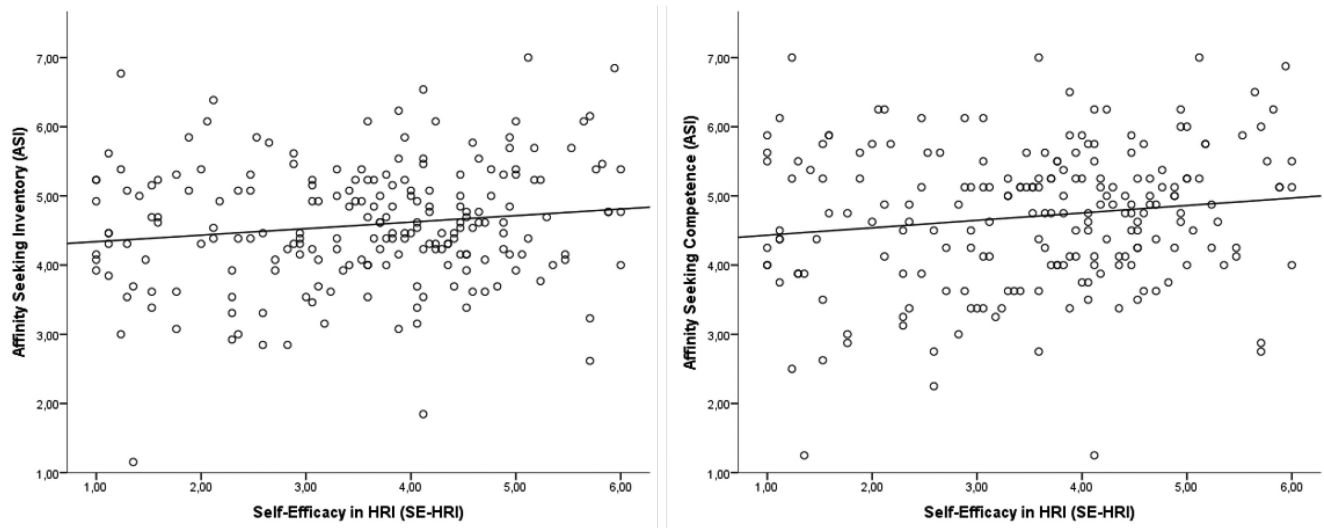

Scatter plots from Study 3 of the correlations between the Self-Efficacy in HRI Scale and the overall Affinity Seeking Inventory (ASI) (left) as well as the Affinity Seeking Competence subscale of the ASI (right).

\section{A.5 Table 3: Short Version of the Self-Efficacy in HRI Scale}

Short version of the self-efficacy in HRI scale, tested with a slider scale from 0 to 100 (especially recommended for senior samples). We included German and English items, and item difficulty.

Instruction:

"Below, you will find several statements regarding your feelings about robots. You should evaluate these statements based on your current constitution. It is not about your potential skills in the future. Example:

"It would be easy for me, to lift a 300lb dumbbell." When evaluating this statement, you should do so based on your current strength, and not based on your potential strength in the future, when you intend to train for it"

\begin{tabular}{cllc}
\hline No. & \multicolumn{1}{c}{ German Item } & \multicolumn{1}{c}{ English Item } & \multicolumn{1}{c}{$\begin{array}{c}\text { Difficulty } \\
\text { (easy) }\end{array}$} \\
\hline 1 & $\begin{array}{l}\text { Ich könnte einen Roboter dazu bringen, } \\
\text { eine bestimmte Aufgabe zu erfüllen. }\end{array}$ & $\begin{array}{l}\text { I could get a robot to perform a } \\
\text { specific task. }\end{array}$ & $56 \%$ \\
$\begin{array}{l}\text { Ich kenne mich gut mit Technik aus, } \\
\text { daher könnte ich auch sicherlich einen } \\
\text { Roboter verwenden. }\end{array}$ & $\begin{array}{l}\text { I am familiar with technology, } \\
\text { therefore, I think I could use a robot. }\end{array}$ & $65 \%$ \\
3 & $\begin{array}{l}\text { Ich denke, ich kann einen Roboter so } \\
\text { einstellen, dass er mich im Alltag }\end{array}$ & $\begin{array}{l}\text { I think I could adjust a robot the way } \\
\text { that it could help me in my daily life. }\end{array}$ & $47 \%$ \\
$\begin{array}{l}\text { unterstützen kann. } \\
\text { Es wäre kein Problem für mich, mit Hilfe } \\
\text { eines Roboters ein bestimmtes Ziel zu } \\
\text { erreichen. }\end{array}$ & $\begin{array}{l}\text { To achieve a specific goal with the } \\
\text { assistance of a robot will not be a } \\
\text { problem for me. }\end{array}$ & $63 \%$ \\
$\begin{array}{l}\text { Wenn ich mich bemühe, könnte ich } \\
\text { einem Roboter etwas beibringen. }\end{array}$ & $\begin{array}{l}\text { I could teach a robot something if I } \\
\text { Ich könnte einem Roboter einfache } \\
\text { Aufgaben beibringen. }\end{array}$ & $\begin{array}{l}\text { I could try hard enough. } \\
\text { easy tasks. }\end{array}$ & $42 \%$ \\
\hline
\end{tabular}




\begin{tabular}{|c|c|c|c|}
\hline No. & German Item & English Item & $\begin{array}{l}\text { Difficulty } \\
\text { (easy) }\end{array}$ \\
\hline 7 & $\begin{array}{l}\text { Ich könnte einfache Einstellungen an } \\
\text { einem Roboter selbst vornehmen. }\end{array}$ & $\begin{array}{l}\text { I could do easy adjustments on a } \\
\text { robot by myself. }\end{array}$ & $50 \%$ \\
\hline 8 & $\begin{array}{l}\text { Ich könnte einen Roboter im Alltag } \\
\text { benutzen. }\end{array}$ & I could use a robot in daily life. & $73 \%$ \\
\hline 9 & $\begin{array}{l}\text { Mit einem Roboter zu interagieren, } \\
\text { würde mir keine Probleme bereiten. }\end{array}$ & $\begin{array}{l}\text { I would feel comfortable while } \\
\text { interacting with the robot. }\end{array}$ & $62 \%$ \\
\hline 10 & $\begin{array}{l}\text { Wenn ein Roboter etwas nicht richtig } \\
\text { macht, finde ich Mittel und Wege dies zu } \\
\text { ändern. }\end{array}$ & $\begin{array}{l}\text { If a robot is doing something wrong, } \\
\text { I could find a way to change its } \\
\text { behavior. }\end{array}$ & $27 \%$ \\
\hline
\end{tabular}

\section{REFERENCES}

[1] Ritu Agarwal, V. Sambamurthy, and Ralph M. Stair. 2000. Research report: The evolving relationship between general and specific computer self-efficacy-An empirical assessment. Information Systems Research 11, 4 (2000), 418-430. DOI : https://doi.org/10.1287/isre.11.4.418.11876

[2] Craig A. Anderson and Kathryn B. Anderson. 1996. Violent crime rate studies in philosophical context: A destructive testing approach to heat and southern culture of violence effects. Fournal of Personality and Social Psychology 70, 4 (1996), 740-756. DOI : https://doi.org/10.1037/0022-3514.70.4.740

[3] pages $=123-456$ publisher $=$ ACM isbn $=9781450343367$ editor $=$ Mutlu, Bilge booktitle $=$ Proceedings of the 2017 ACMIEEE International Conference on Human-Robot Interaction year $=2017$ address $=[$ S.l. $]$ doi $=123-456$ anonymized, title = anonymized paper. [n. d.].

[4] Paul Arnstein, Margaret Caudill, Carol Lynn Mandle, Anne Norris, and Ralph Beasley. 1999. Self efficacy as a mediator of the relationship between pain intensity, disability and depression in chronic pain patients. Pain 80, 3 (1999), 483491. DOI : https://doi.org/10.1016/S0304-3959(98)00220-6

[5] Albert Bandura. 1986. The explanatory and predictive scope of self-efficacy theory. fournal of Social and Clinical Psychology 4, 3 (1986), 359-373. DOI : https://doi.org/10.1521/jscp.1986.4.3.359

[6] Albert Bandura. 2006. Guide for constructing self-efficacy scales. Self-efficacy Beliefs of Adolescents 5, 307337 (2006).

[7] Albert Bandura, Nancy E. Adams, and Janice Beyer. 1977. Cognitive processes mediating behavioral change. fournal of Personality and Social Psychology 35, 3 (1977), 125-139. DOI : https://doi.org/10.1037/0022-3514.35.3.125

[8] M. S. Bartlett. 1937. Properties of sufficiency and statistical tests. Proceedings of the Royal Society A: Mathematical, Physical and Engineering Sciences 160, 901 (1937), 268-282. DOI : https://doi.org/10.1098/rspa.1937.0109

[9] Christoph Bartneck, Dana Kulić, Elizabeth Croft, and Susana Zoghbi. 2009. Measurement instruments for the anthropomorphism, animacy, likeability, perceived intelligence, and perceived safety of robots. International fournal of Social Robotics 1, 1 (2009), 71-81. DOI : https://doi.org/10.1007/s12369-008-0001-3

[10] Guido Beier. 1999. Kontrollüberzeugungen im umgang mit technik. Report Psychologie 9 (1999), 684-693.

[11] Robert A. Bell, Sheryl W. Tremblay, and Nancy L. Buerkel-Rothfuss. 1987. Interpersonal attraction as a communication accomplishment: Development of a measure of affinity-seeking competence. Western fournal of Speech Communication 51, 1 (1987), 1-18. DOI : https://doi.org/10.1080/10570318709374249

[12] Jürgen Bortz. 1999. Statistik: Für Sozialwissenschaftler (fünfte, vollständig überarbeitete und aktualisierte auflage ed.). Springer Berlin Heidelberg, Berlin, Heidelberg and s.l. DOI : https://doi.org/10.1007/978-3-662-10031-8

[13] Gregory J. Boyle. 1985. Self-report measures of depression: Some psychometric considerations. British fournal of Clinical Psychology 24, 1 (1985), 45-59. DOI : https://doi.org/10.1111/j.2044-8260.1985.tb01312.x

[14] Gregory J. Boyle. 1991. Does item homogeneity indicate internal consistency or item redundancy in psychometric scales? Personality and Individual Differences 12, 3 (1991), 291-294. DOI : https://doi.org/10.1016/0191-8869(91)90115-R

[15] Timothy A. Brown. 2015. Confirmatory Factor Analysis for Applied Research (2nd ed.). Guilford Press, New York, NY.

[16] Marlene E. Burkhardt and Daniel J. Brass. 1990. Changing patterns or patterns of change: The effects of a change in technology on social network structure and power. Administrative Science Quarterly 35, 1 (1990), 104. DOI : https:// doi.org/10.2307/2393552

[17] E. Carmines and J. McIver. 1981. Analyzing models with unobserved variables: Analysis of covariance structures. In Social Measurement: Current Issues, G. Bohrnstedt and E. Borgatta (Eds.). Sage, Beverly Hills, CA. 
[18] Simon Cassidy and Peter Eachus. 2002. Developing the computer user self-efficacy (CUSE) scale: Investigating the relationship between computer self-efficacy, gender and experience with computers. fournal of Educational Computing Research 26, 2 (2002), 133-153. DOI : https://doi.org/10.2190/JGJR-0KVL-HRF7-GCNV

[19] R. B. Cattell. 1966. The scree test for the number of factors. Multivariate Behavioral Research 1, 2 (1966), $245-276$. DOI : https://doi.org/10.1207/s15327906mbr0102_10

[20] Vehbi Celik and Etem Yesilyurt. 2013. Attitudes to technology, perceived computer self-efficacy and computer anxiety as predictors of computer supported education. Computers \& Education 60, 1 (2013), 148-158. DOI : https://doi.org/10. 1016/j.compedu.2012.06.008

[21] Gilad Chen, Stanley M. Gully, and Dov Eden. 2001. Validation of a new general self-efficacy scale. Organizational Research Methods 4, 1 (2001), 62-83. DOI : https://doi.org/10.1177/109442810141004

[22] Kuanchin Chen, Jengchung V. Chen, and David C. Yen. 2011. Dimensions of self-efficacy in the study of smart phone acceptance. Computer Standards \& Interfaces 33, 4 (2011), 422-431. DOI : https://doi.org/10.1016/j.csi.2011.01.003

[23] Jacob Cohen. 1988. Statistical power analysis for the behavioral sciences, Vol. 2. Lawrence Earlbaum Associates, Hilsdale, NJ .

[24] Sheldon Cohen and Harry M. Hoberman. 1983. Positive events and social supports as buffers of life change stress. fournal of Applied Social Psychology 13, 2 (1983), 99-125. DOI : https://doi.org/10.1111/j.1559-1816.1983.tb02325.x

[25] Sheldon Cohen, Robin Mermelstein, Tom Kamarck, and Harry M. Hoberman. 1985. Measuring the Functional Components of Social Support. DOI : https://doi.org/10.1007/978-94-009-5115-0 \textunderscore

[26] Deborah Compeau, Christopher A. Higgins, and Sid Huff. 1999. Social cognitive theory and individual reactions to computing technology: A longitudinal study. MIS Quarterly 23, 2 (1999), 145. DOI : https://doi.org/10.2307/249749

[27] Deborah R. Compeau and Christopher A. Higgins. 1995. Application of social cognitive theory to training for computer skills. Information Systems Research 6, 2 (1995), 118-143.

[28] Deborah R. Compeau and Christopher A. Higgins. 1995. Computer self-efficacy: Development of a measure and initial test. MIS Quarterly 19, 2 (1995), 189-211. DOI: https://doi.org/10.2307/249688

[29] J. D. Cook, S. J. Hepworth, T. D. Wall, and P. B. Warr. 1981. The experience of work: A compendium and review of 249 factors and their use.

[30] H. Coolican. 2017. Research Methods and Statistics in Psychology. Taylor \& Francis.

[31] Robert Devellis. 2003. Scale Development: Theory and Applications, (2nd Ed.). Sage Publications, Inc.

[32] Eamonn Ferguson and Tom Cox. 1993. Exploratory factor analysis: A user's guide. International fournal of Selection and Assessment 1, 2 (1993), 84-94. DOI : https://doi.org/10.1111/j.1468-2389.1993.tb00092.x

[33] Andy P. Field. 2009. Discovering Statistics Using SPSS : (And Sex and Drugs and Rock 'n' Roll) (3rd ed.). SAGE Publications Inc., Thousand Oaks, CA and London. DOI : http://worldcatlibraries.org/wcpa/oclc/262584404

[34] forsa. 2016. Service-Robotik: Mensch-Technik-Interaktion im Alltag: Ergebnisse einer repräsentativen Befragung. DOI : https://www.bmbf.de/files/BMBF_forsa_Robotik_FINAL2016.pdf.

[35] Marilyn E. Gist, Catherine Schwoerer, and Benson Rosen. 1989. Effects of alternative training methods on self-efficacy and performance in computer software training. Fournal of Applied Psychology 74, 6 (1989), 884-891. DOI : https://doi. org/10.1037/0021-9010.74.6.884

[36] Robert J. Harvey, Robert S. Billings, and Kevin J. Nilan. 1985. Confirmatory factor analysis of the job diagnostic survey: Good news and bad news. Journal of Applied Psychology 70, 3 (1985), 461-468. D0I : https://doi.org/10.1037/ 0021-9010.70.3.461

[37] John L. Horn. 1965. A rationale and test for the number of factors in factor analysis. Psychometrika 30, 2 (1965), 179-185. DOI : https://doi.org/10.1007/BF02289447

[38] Meng-Hsiang Hsu and Chao-Min Chiu. 2004. Internet self-efficacy and electronic service acceptance. Decision Support Systems 38, 3 (2004), 369-381. DOI : https://doi.org/10.1016/j.dss.2003.08.001

[39] Li-tze Hu and Peter M. Bentler. 1999. Cutoff criteria for fit indexes in covariance structure analysis: Conventional criteria versus new alternatives. Structural Equation Modeling: A Multidisciplinary fournal 6, 1 (1999), 1-55. DOI : https://doi.org/10.1080/10705519909540118

[40] Graeme D. Hutcheson and Nick Sofroniou. 1999. The Multivariate Social Scientist: Introductory Statistics Using Generalized Linear Models. SAGE Publications, Ltd, London. DOI : https://doi.org/10.4135/9780857028075

[41] M. Igbaria. 1995. The effects of self-efficacy on computer usage. Omega 23, 6 (1995), 587-605. DOI : https://doi.org/10. 1016/0305-0483(95)00035-6

[42] Monique Janneck, Sylvie Vincent-Höper, and Ina Othersen. 2012. Entwicklung und validierung eines fragebogens zum technikbezogenen selbstkonzept (TSK): Eine gendersensitive Studie. Gruppendynamik und Organisationsberatung 43, 3 (2012), 289-310. DOI : https://doi.org/10.1007/s11612-012-0184-9

[43] Henry F. Kaiser. 1974. An index of factorial simplicity. Psychometrika 39, 1 (1974), 31-36. DOI : https://doi.org/10.1007/ BF02291575 
[44] Henry F. Kaiser and Kern W. Dickman. 1959. Analytic determination of common factors. In American Psychologist. Vol. 14. 425-441.

[45] Paul Kline. 1979. Psychometrics and Psychology. Acad. Press, London.

[46] Cynthia Lee and Philip Bobko. 1994. Self-efficacy beliefs: Comparison of five measures. Fournal of Applied Psychology 79, 3 (1994), 364-369. DOI : https://doi.org/10.1037/0021-9010.79.3.364

[47] Joseph Lee Rodgers and W. Alan Nicewander. 1988. Thirteen ways to look at the correlation coefficient. The American Statistician 42, 1 (1988), 59-66. DOI : https://doi.org/10.1080/00031305.1988.10475524

[48] Jing Li, Jean-Bernard Martens, and Jarke J. van Wijk. 2008. Judging correlation from scatterplots and parallel coordinate plots. Information Visualization 9, 1 (2008), 13-30. DOI : https://doi.org/10.1057/ivs.2008.13

[49] Gitta H. Lubke and Bengt O. Muthén. 2004. Applying multigroup confirmatory factor models for continuous outcomes to Likert scale data complicates meaningful group comparisons. Structural Equation Modeling: A Multidisciplinary Journal 11, 4 (2004), 514-534. DOI : https://doi.org/10.1207/s15328007sem1104\textunderscore

[50] P. K. MACIEJEWSKI. 2000. Self-efficacy as a mediator between stressful life events and depressive symptoms: Differences based on history of prior depression. The British fournal of Psychiatry 176, 4 (2000), 373-378. DOI : https:// doi.org/10.1192/bjp.176.4.373

[51] Tracy McDonald and Marc Siegall. 1992. The effects of technological self-efficacy and job focus on job performance, attitudes, and withdrawal behaviors. Journal of Psychology 126, 5 (1992), 465.

[52] Takumi Ninomiya, Akihito Fujita, Daisuke Suzuki, and Hiroyuki Umemuro (Eds.). 2015. Development of the Multidimensional Robot Attitude Scale: Constructs of People's Attitudes Towards Domestic Robots. Springer International Publishing. DOI : https://doi.org/10.1007/978-3-319-25554-5\textunderscore

[53] Tatsuya Nomura, Takayuki Kanda, and Tomohiro Suzuki. 2006. Experimental investigation into influence of negative attitudes toward robots on human-robot interaction. AI \& SOCIETY 20, 2 (2006), 138-150. DOI : https://doi.org/10. 1007/s00146-005-0012-7

[54] F. Pajares. 1996. Self-efficacy beliefs in academic settings. Review of Educational Research 66, 4 (1996), 543-578. DOI : https://doi.org/10.3102/00346543066004543

[55] Frank Pajares and M. David Miller. 1994. Role of self-efficacy and self-concept beliefs in mathematical problem solving: A path analysis. fournal of Educational Psychology 86, 2 (1994), 193-203. DOI : https://doi.org/10.1037/0022-0663. 86.2 .193

[56] B. Phillips and H. Zhao. 1993. Predictors of assistive technology abandonment. Assistive Technology : The Official Journal of RESNA 5, 1 (1993), 36-45. DOI : https://doi.org/10.1080/10400435.1993.10132205

[57] Rosenthal-von der Pütten, Astrid M. and Nicole C. Krämer. 2015. Individuals' evaluations of and attitudes towards potentially uncanny robots. International fournal of Social Robotics 7, 5 (2015), 799-824. DOI : https://doi.org/10.1007/ s12369-015-0321-z

[58] Albert Satorra. 2000. Scaled and adjusted restricted tests in multi-sample analysis of moment structures. In Innovations in Multivariate Statistical Analysis, R. D. H. Heijmans, D. S. G. Pollock, and A. Satorra (Eds.). Advanced Studies in Theoretical and Applied Econometrics, Vol. 36. Springer, Boston, MA, 233-247. DOI : https://doi.org/10.1007/ 978-1-4615-4603-0\$ \delimeter'026E30F\$textunderscore

[59] Karin Schermelleh-Engel, Helfried Moosbrugger, and Hans Müller. 2003. Evaluating the fit of structural equation models: Tests of significance and descriptive goodness-of-fit measures. Methods of Psychological Research Online 8, 2 (2003), 23-74.

[60] R. Schwarzer and M. Jerusalem. 1995. Generalized self-efficacy scale. f. Weinman, S. Wright, \& M. fohnston, Measures in Health Psychology: A User's Portfolio Causal and Control Beliefs. Windsor, UK: NFER-NELSON(1995), 35-37.

[61] Christa Speier and Michael Frese. 1997. Generalized self efficacy as a mediator and moderator between control and complexity at work and personal initiative: A longitudinal field study in East Germany. Human Performance 10, 2 (1997), 171-192. DOI : https://doi.org/10.1207/s15327043hup1002\{_\}7

[62] D. Sandy Staples, John S. Hulland, and Christopher A. Higgins. 1998. A self-efficacy theory explanation for the management of remote workers in virtual organizations. Journal of Computer-Mediated Communication 3, 4 (1998), 0 DOI : https://doi.org/10.1111/j.1083-6101.1998.tb00085.x

[63] James Paul Stevens. 2009. Applied Multivariate Statistics for the Social Sciences (5. ed.). Routledge, New York. DOI: http://site.ebrary.com/lib/alltitles/docDetail.action?docID=10617648

[64] Gholamreza Torkzadeh, Xenophon Koufteros, and Kurt Pflughoeft. 2003. Confirmatory analysis of computer selfefficacy. Structural Equation Modeling: A Multidisciplinary fournal 10, 2 (2003), 263-275. DOI : https://doi.org/10.1207/ S15328007SEM1002\{_\}6

[65] Gholamreza Torkzadeh and Thomas P. van Dyke. 2001. Development and validation of an internet self-efficacy scale. Behaviour \& Information Technology 20, 4 (2001), 275-280. DOI : https://doi.org/10.1080/01449290110050293

[66] Gholamreza Torkzadeh and Thomas P. van Dyke. 2002. Effects of training on Internet self-efficacy and computer user attitudes. Computers in Human Behavior 18, 5 (2002), 479-494. DOI : https://doi.org/10.1016/S0747-5632(02)00010-9 
[67] W. F. Velicer, A. C. Peacock, and D. N. Jackson. 1982. A comparison of component and factor patterns: A Monte Carlo approach. Multivariate Behavioral Research 17, 3 (1982), 371-388. DOI : https://doi.org/10.1207/s15327906mbr1703\{_\}5

[68] Viswanath Venkatesh and Fred D. Davis. 1996. A model of the antecedents of perceived ease of use: Development and test. Decision Sciences 27, 3 (1996), 451-481. DOI : https://doi.org/10.1111/j.1540-5915.1996.tb00860.x

[69] Viswanath Venkatesh, Michael Morris, Gordon Davis, and Fred Davis. 2003. User acceptance of information technology: Toward a unified view. Management Information Systems Quarterly 27, 3 (2003). DOI : http://aisel.aisnet.org/ $\mathrm{misq} / \mathrm{vol} 27 /$ iss $3 / 5$

[70] Nicole C. Krämer, Laura Hoffmann, Alberto Fuchslocher, Sabrina C. Eimler, Jessica M. Szczuka, Matthias Brand, Jennifer Klatt, Anh Lam-chi, and Nicole Sträafling. 2013. Do I need to belong? Development of a scale for measuring the need to belong and its predictive value for media usage. In Proceedings of the Annual Conference of the International Communication Association, Vol. 1721.

[71] Frederick J. Gravetter and Lori-Ann B. Forzano. 2011. Research Methods for the Behavioral Sciences (4th ed.). Wadsworth and Cengage Learning (Distributor).

Received October 2017; revised July 2018; accepted August 2018 